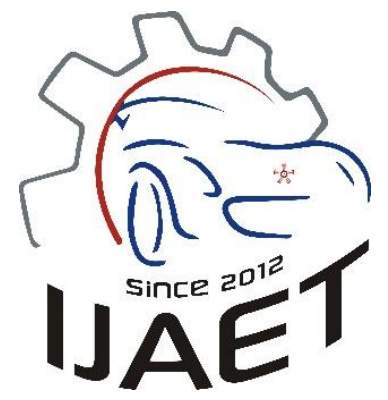

e-ISSN: 2146 - 9067

International Journal of Automotive

Engineering and Technologies

journal homepage: http://ijaet.academicpaper.org

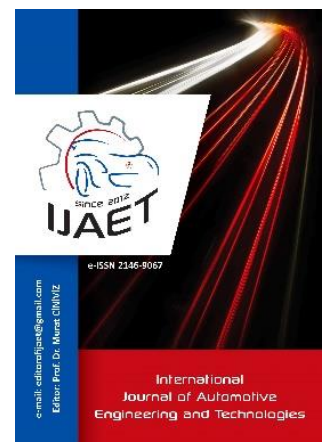

Original Research Article

\title{
A Review Study on the Using of Diethyl Ether in Diesel Engines: Effects on NOx Emissions
}

hosted by

Jurkish

\author{
İsmet Sezer ${ }^{1 *}$ \\ ${ }^{1}$ Department of Mechanical Engineering, Gümüşhane University, Gümüşhane, Turkey
}

\begin{abstract}
ARTICLE INFO
* Corresponding author isezer@gumushane.edu.tr

Received: October 26, 2018

Accepted: December 19, 2018

Published by Editorial Board Members of IJAET

(C) This article is distributed by Turk Journal Park System under the $\mathrm{CC} 4.0$ terms and conditions.
\end{abstract}

\begin{abstract}
This study was compiled from the results of various researches performed on using diethyl ether as a fuel or fuel additive in diesel engines. Three different techniques have used the reduction of the harmful exhaust emissions of diesel engines. The first technique for the reduction of harmful emissions has improved the combustion by modification of engine design and fuel injection system, but this process is expensive and time-consuming. The second technique is the using various exhaust gas devices like catalytic converter and diesel particulate filter. However, the use of these devices affects negatively diesel engine performance. The final technique to reduce emissions and improve diesel engine performance is the use of various alternative fuels or fuel additives. The major pollutants of diesel engines are an oxide of nitrogen (NOx) and smoke or particulate matter (PM). It is very difficult to reduce NOx and PM simultaneously in practice. The most researches declare that the best way to reduce is the use of various alternative fuels i.e. natural gas, biogas, biodiesel or using additives with alternative fuels or conventional diesel fuel. Therefore, it is very important that the results of various studies on alternative fuels or fuel additives are evaluated together to practical applications. Especially, this study focuses on the use of diethyl ether in diesel engines as fuel or fuel additive in various diesel engine fuels. This review study investigates the effects of diethyl ether addition on the NOx emissions.
\end{abstract}

Keywords: Diesel engine performance, NOx emissions, Fuel additives, Diethyl ether

\section{Introduction}

Diesel engines are widely used in both light and heavy-duty vehicles [1]. They are reliable, robust and the most efficient internal combustion engines [2]. However, diesel engines suffer from their high emission drawbacks like particulate matters (PM), total gaseous hydrocarbons (THC), nitrogen oxides (NOx), sulphur oxides (SOx) and smoke [3, 4]. It is seeming that the most suitable way to reduce of these emissions is the using of alternative fuels made from renewable sources instead of commercial fuels [5]. However, complete replacement of fossil fuels with renewable alternative fuels will require a 
comprehensive modification of the engine hardware and their combustion in the engine results in operational and technical limitations [6]. The fuel side modification techniques such as blending, emulsification and oxygenation are the easy way for emission reduction without any modification on the engine hardware. Modification of diesel fuel to reduce exhaust emission can be performed by increasing the cetane number, reducing fuel sulphur, reducing aromatic content, increasing fuel volatility and decreasing the fuel density to have the compromise between engine performance and engine-out emissions, one such change has been the possibility of using diesel fuels with oxygenates [7]. Among different alternative fuels, oxygenated fuel is a kind of alternative fuel. Diethylene glycol dimethyl ether (DGM), dimethoxy methane (DMM), dimethyl ether (DME), methyl tertiary butyl ether (MTBE), dibutyl ether (DBE), dimethyl carbonate (DMC), methanol, ethanol and diethyl ether (DEE) have played their role to reduce diesel emissions [7-9]. These fuels can either be used as a blend with conventional diesel fuel or pure. These additives can also be used in combination with biodiesel [10]. The presence of oxygen in the fuel molecular structure plays an important role to reduce PM and other harmful emissions from diesel engines. However, NOx emissions can be reduced in some cases and be increased depending on the engine operating conditions $[11,12]$. Especially, DEE is a suitable fuel for diesel engines because it is a cetane improver besides an oxygenated fuel [13]. Therefore, this review study is devoted to the use of DEE in diesel engines as fuel or fuel additive in various diesel engine fuels.

\section{Properties of Diethyl Ether}

Diethyl ether is the simplest ether expressed by its chemical formula $\mathrm{CH} 3 \mathrm{CH} 2-\mathrm{O}-\mathrm{CH} 2 \mathrm{CH} 3$, consisting of two ethyl groups bonded to a central oxygen atom as seen in Fig. 1.

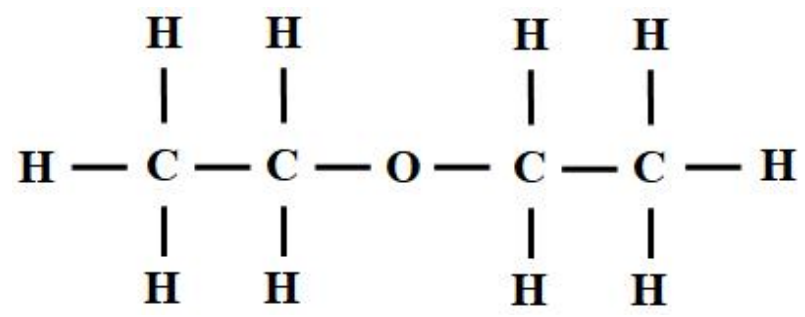

Fig. 1. Diethyl ether chemical composition [3]
Diethyl ether (DEE) is regarded as one of the promising alternative fuels or an oxygen additive for diesel engines with its advantages of a high cetane number and oxygen content. DEE is liquid at the ambient conditions, which makes it attractive for fuel storage and handling. DEE is produced from ethanol by dehydration process as seen in Fig. 2 so it is a renewable fuel [14].

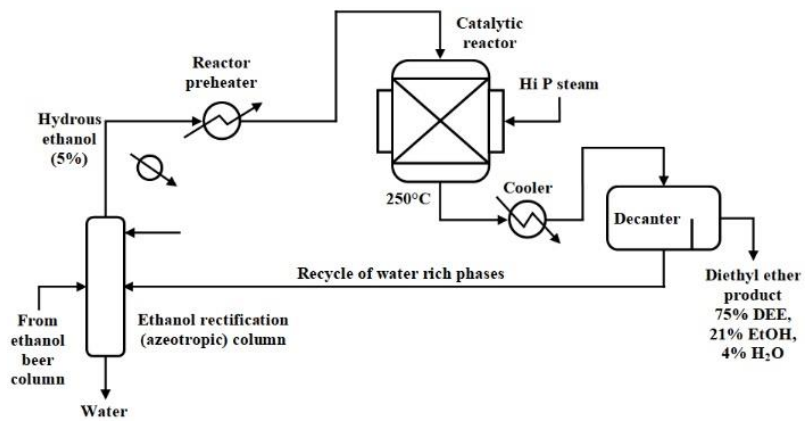

Fig. 2. Production of diethyl ether from ethanol [14]

As shown in Table 1, DEE has several favorable properties, including exceptional cetane number, reasonable energy density, high oxygen content, low auto ignition temperature and high volatility. Therefore, it can be assisting in improving engine performance and reducing the cold starting problem and emissions when using as a pure or an additive in diesel engines [14, 15].

Table 1. The main fuel properties of diesel fuel and DEE [15].

\begin{tabular}{|c|c|c|}
\hline Property & Diesel & $\overline{\mathrm{DEE}}$ \\
\hline Chemical formula & $\overline{\mathrm{C}_{\mathrm{x}} \mathrm{H}_{\mathrm{y}}}$ & $\mathrm{C}_{4} \mathrm{H}_{10} \mathrm{O}$ \\
\hline Molecular weight & $190-220$ & 74 \\
\hline Density of liquid at NTP* $(\mathrm{kg} / \mathrm{L})$ & $\sim 0.84$ & 0.71 \\
\hline Viscosity at NTP* (cP) & 2.6 & 0.23 \\
\hline Oxygen content (wt \%) & 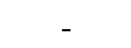 & 21 \\
\hline Sulphur content (ppm) & $\sim 250$ & - \\
\hline Boiling temperature $\left({ }^{\circ} \mathrm{C}\right)$ & $180-360$ & 34.6 \\
\hline Auto ignition temperature in air, ${ }^{\circ} \mathrm{C}$ & 315 & 160 \\
\hline Flammability limit in air (vol \%) & $0.6-6.5$ & $1.9-9.5$ \\
\hline $\begin{array}{l}\text { Stoichiometric air-fuel ratio } \\
\left(\mathrm{AFR}_{\mathrm{s}}\right)\end{array}$ & 14.6 & 11.1 \\
\hline $\begin{array}{l}\text { Heat of vaporization at NTP* } \\
(\mathrm{kJ} / \mathrm{kg})\end{array}$ & 250 & 356 \\
\hline Lower heating value (MJ/kg) & 42.5 & 33.9 \\
\hline Cetane number $(\mathrm{CN})$ & $40-55$ & 125 \\
\hline
\end{tabular}

*NTP: Normal temperature and pressure

There are some challenges with DEE such as storage stability, flammability limits and lower lubricity. Storage stability of DEE and DEE blends are of concern because of a tendency to oxidize, forming peroxides in storage. It is suggested that antioxidant additives may be 
available to prevent storage oxidation. Flammability limits for DEE as seen in Table 1 are broader than those of many fuels, but the rich flammability limit of DEE is in question [14].

\section{Studies on Diethyl Ether in Literature}

There are several studies in the literature on the use of DEE in diesel engines as a fuel or fuel additive in various diesel engine fuels. For example; as pure [16], with diesel fuel [17-32], with diesel-ethanol blends [33-40], with dieselferric chloride blends [41], with diesel-kerosene blends [42], with diesel-acetylene gas dual fuel [43], with biogas [44], with liquefied petroleum gas [45], with diesel-natural gas dual fuel [46], with ethanol [47, 48], with various biodiesel fuels [49-68], with biogas-biodiesel blends [69], with water-biodiesel emulsion fuel [70], with various biodiesel-diesel blends [71-109], with ethanol-biodiesel-diesel blends [110-113] and methanol-biodiesel-diesel blends [113].

\section{Effects of Diethyl Ether on NOx Emissions}

Sezer [15] declared that NO emission became higher for equal equivalence ratio condition, while it was lower for equal mass fuel injection condition for DEE. The reduction in NO emission was achieved by lower combustion temperatures. However, increases in NO emission for equal equivalence ratio condition could be attributed to rises in combustion temperatures of DEE and abundant oxygen sourced from the increased mass of DEE. The higher combustion temperature led to dissociation reactions and abundant oxygen in the combustion chamber contributed dissociation products such as NO. Rakopoulos et al [17] declared that NOx emitted by all DEEdiesel blends were lower than diesel fuel as seen in Fig. 3(a). The reduction is higher for higher the percentage of DEE in the blend. This might be attributed to the engine running overall leaner and the temperature lowering effect of the DEE having the dominating influence, partially outweighed by the extra fuel-bound oxygen bringing more 'zones' near to stoichiometric conditions and little to the lean, where NOx was highly formed. Banapurmath et al [22] declared that the formation rate of NOx is primarily a function of flame temperature, the residence time of nitrogen at that temperature and the availability of oxygen in the combustion chamber. NOx emission was increased with the engine load as seen in Fig. 3(b). This was due to the increased quantity of fuel is injected and combusted in the cylinder when engine load increased, which caused higher gas temperature and resulted in more NOx formation. It also can be seen that NOx emission was slightly reduced with DEE blends compared to diesel fuel. This was due to low combustion temperature because of low calorific value and the high latent heat of vaporization of DEE resulted in reduced flame temperature and lower NOx emissions.

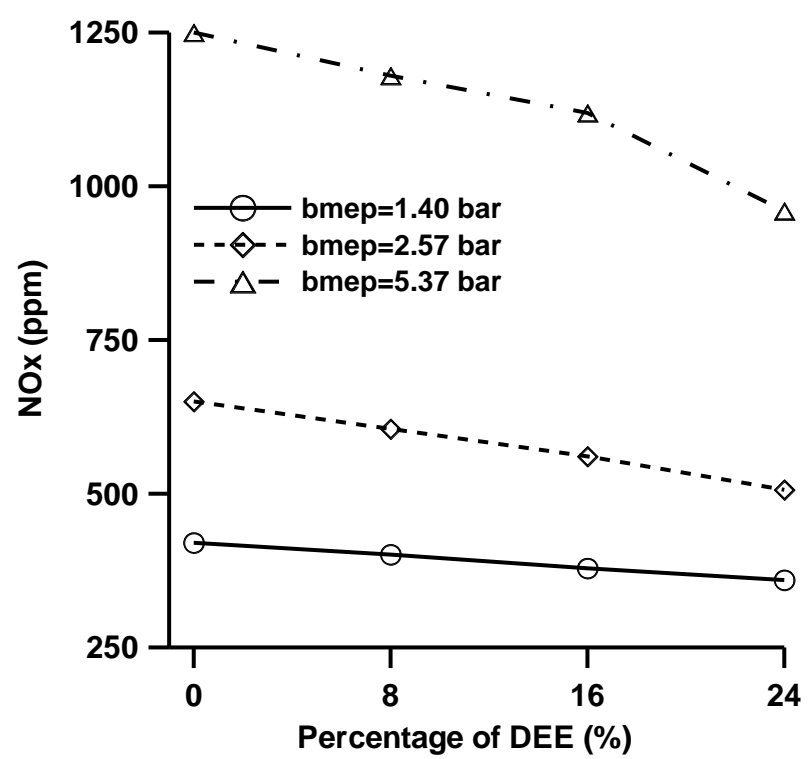

(a)

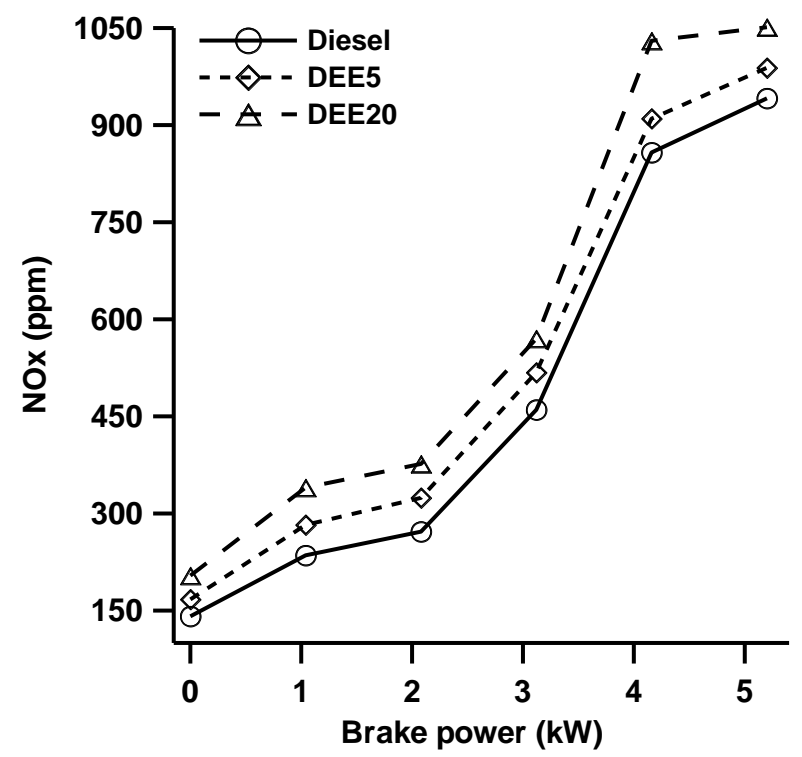

(b)

Fig. 3. Effect of diethyl ether additive on NOx emissions of the diesel fuel $[17,22]$

Lee and Kim [23] declared that NOx was the lowest at a low engine load because excess air cooled down the mixture, resulting in low $\mathrm{NO}_{\mathrm{x}}$ emissions. NOx emissions for diesel were lower 
than DEE blends and increased with increasing in DEE content as seen in Fig. 4(a). Formation of NOx emissions was strongly dependent on the cylinder peak temperature and local oxygen concentration. The oxygen content of DEE brought more zones near to stoichiometric conditions and little to the lean, and these conditions favor for NOx formation. Additional oxygen availability resulted in the more complete combustion of the fuel-air mixture and increased the burned gas, which tended to be converted into more NOx in the hightemperature regions during combustion. One more possible explanation for the higher NOx emissions of the blended fuels was the shorter ignition delay due to the addition of DEE.

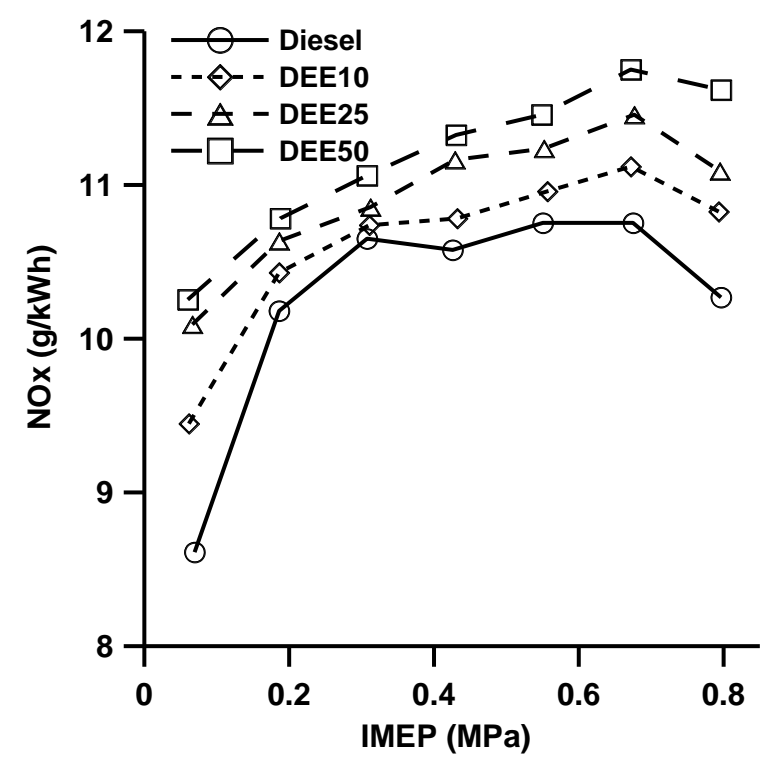

(a)

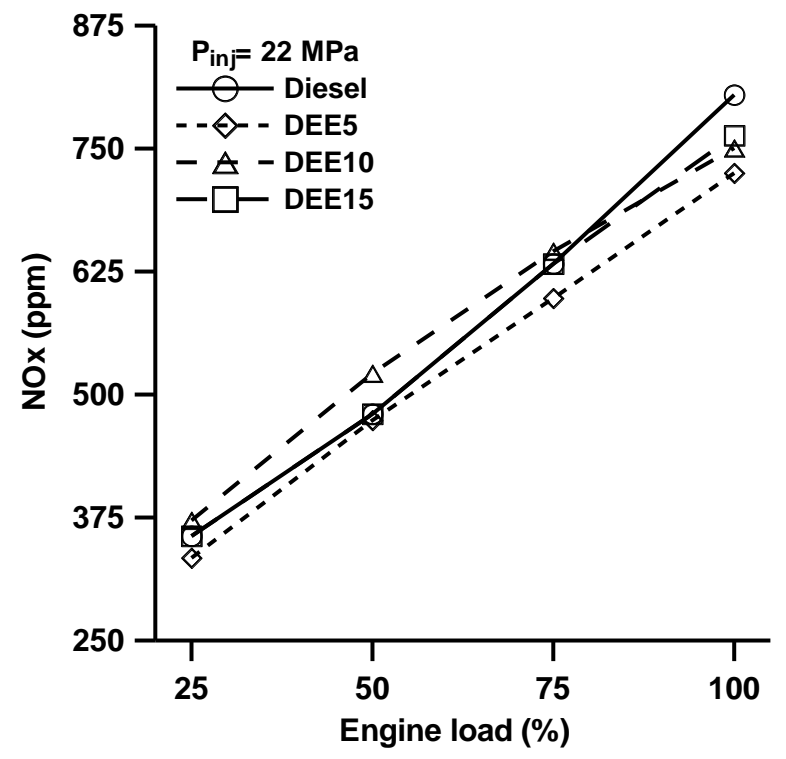

(b)

Fig. 4. Effect of diethyl ether additive on NOx emissions of the diesel fuel [23, 29]

Saravanan et al [24] declared that NOx emissions slightly decreased with DEE addition. The reduction in the peak combustion temperature due to the addition of DEE which reduced the calorific value of the blend helped in reducing the NOx emissions. The reduced ignition delay period and shortened combustion duration due to higher cetane number of DEE also helped in reducing the NOx emission. Madhu et al [29] declared that NOx emission was reduced with blending DEE to diesel as seen in Fig. 4 (b). At a given injection pressure, as the composition of DEE increased, NOx also increased. However, as the injection pressure and composition of DEE increased, NOx emission was found to be decreasing. There was $9 \%$ reduction in NOx with E5D95 at $22 \mathrm{MPa}$ injection pressure. This was due to the diminishing fuel particle size at higher pressures and enhanced mixing of fuel with air. Higher injection pressure generated faster combustion rates and as the premixed combustion was shortened, the peak cylinder temperature reduced with the addition of DEE.

Prasadarao et al [31] declared all the blends tested produced higher NOx emission than diesel fuel except for BD15DEE5, while biodiesel fuel had lower NOx emissions than diesel fuel at higher loads as seen in Fig. 5(a). As cetane number of biodiesel fuel was higher than diesel, it exhibited a shorter delay period and resulted in better combustion leading to low NO emissions but when it was blended with DEE produced more NO emission. On the other hand, the remarkable reduction was obtained with BD15DEE5.

Cinar et al [32] declared that NOx emissions were reduced with increase in the premixed DEE fuel ratio. NOx emissions were mostly generated by thermal mechanisms during the diffusion combustion stage. Most of the heat release rate occurred during the premixed combustion phase and the diffusion combustion phase decreased with the increasing premixed ratio of DEE. Therefore, the main combustion occurred after TDC and thus resulted in lower $\mathrm{NO}_{\mathrm{x}}$ emissions caused by cylinder temperatures. NOx emissions were decreased by $19.4 \%$ under HCCI-DI operating conditions as seen in Fig. 5(b). Iranmanesh [33] declared that as the quantity of DEE in the blends increased, 
dynamic injection timing was altered due to problems encountered with the fuel pump and lowering the density, viscosity and bulk modulus of the blends which led to late injection and consequently ignition retard. Then, the start of combustion and heat release was postponed. Moreover, due to the high latent heat of DEE, the peak pressure and peak heat release rate were suppressed, hence as a result of these two factors NOx emissions drastically reduced as seen in Fig. 6(a). Ethanol and DEE blending into diesel fuel reduced temperature both by increased heat of vaporization and reduced flame temperature. Consequently, combustion temperature abated, and hence NOx emissions were diminished. The blend of E10DEE8 had the lowest NOx emissions such that $36.6 \%$ and $43 \%$ improvement was observed at full load condition in compare with E10 blend and diesel fuel respectively.

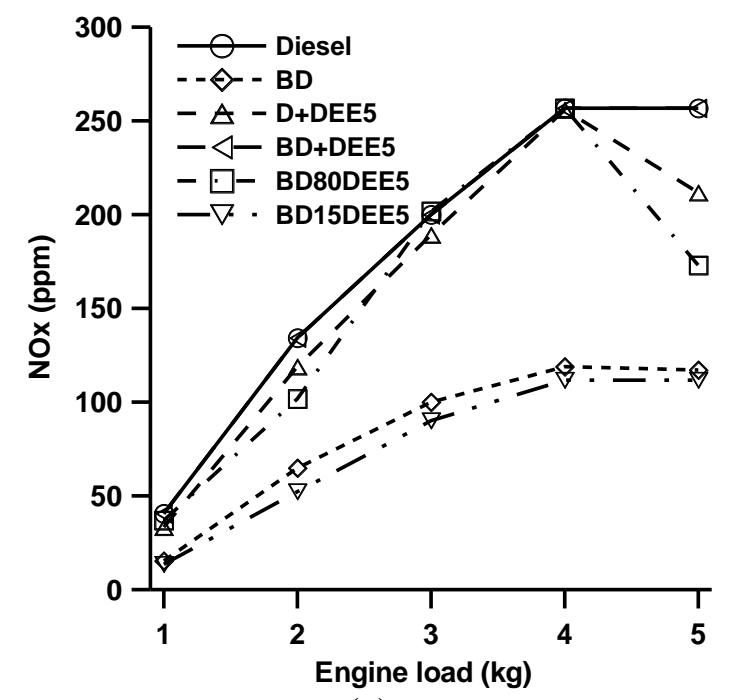

(a)

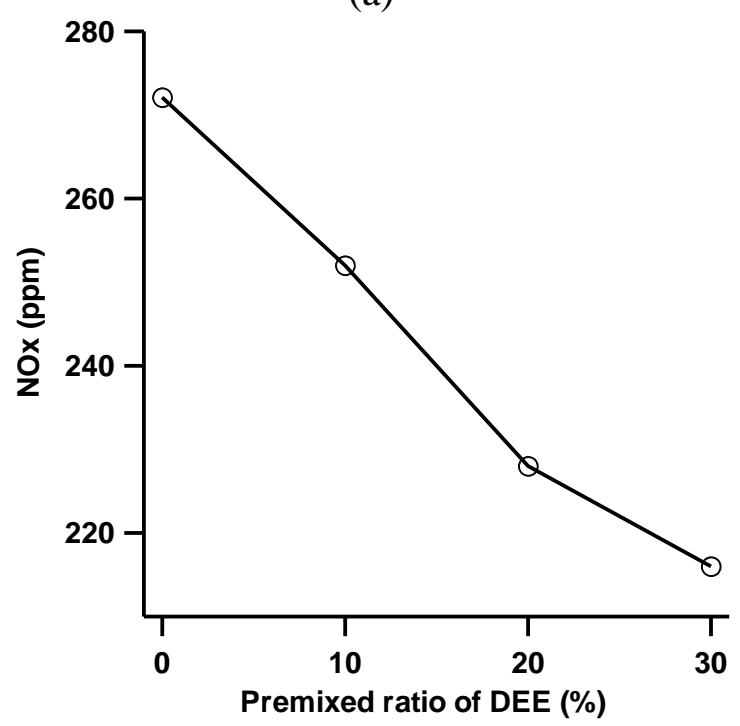

(b)

Fig. 5. Effect of diethyl ether additive on NOx emissions

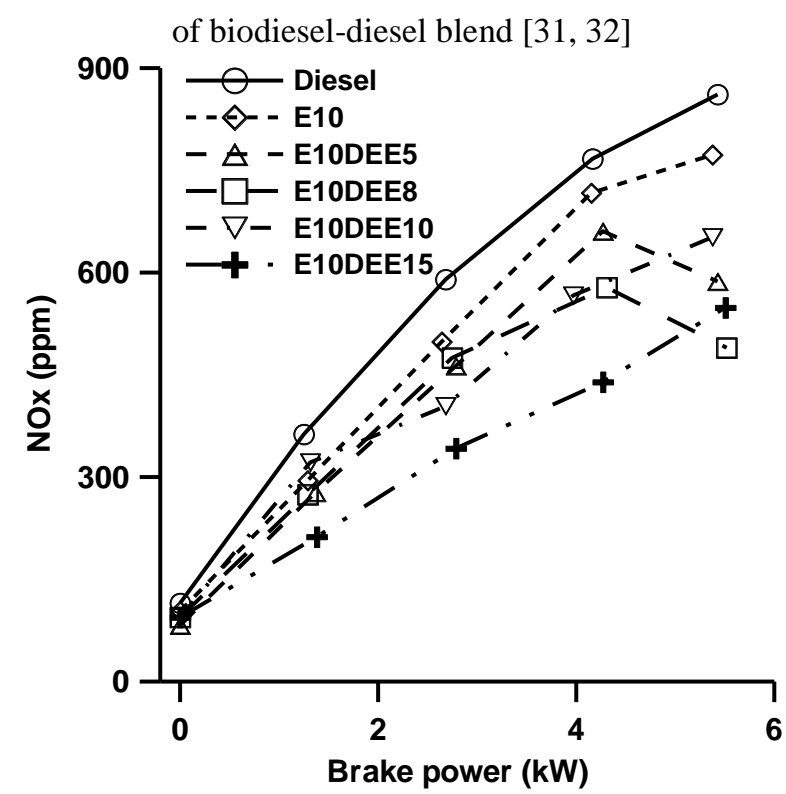

(a)

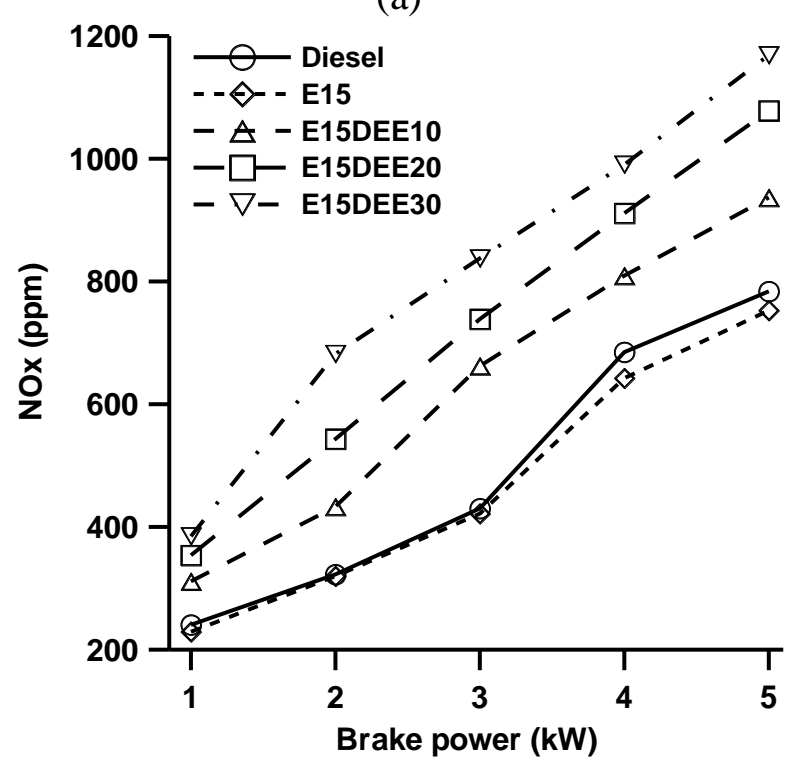

(b)

Fig. 6. Effect of diethyl ether additive on NOx emissions of ethanol-diesel blends [33, 35]

Sudhakar and Sivaprakasam [35] declared that ethanol blended diesel E15 showed a slight decrease in NOx, when the injection percentages of DEE increased the NOx emissions were increasing drastically as seen in Fig. 6(b). This was mainly due to oxygen available in DEE increased the cylinder temperature while combustion took place that led to the formation of oxides of nitrogen and that was evidently proved in heat release rate and exhaust temperature of the test engine. The highest $48 \%$ increase in NOx emission was recorded at $30 \%$ of DEE injection while comparing with diesel fuel. Sudhakar and Sivaprakasam [36] declared that the fumigation of DEE in large quantity increased NOx 
emission by $49 \%$. The increasing percentage of DEE injection marginally increased the NOx emission. However, the EGR revealed good control over the NOx emission reduction. Paul et al [37] declared that NOx emission decreased with DEE5 blend at low load but increased with medium and high load conditions. At lower load conditions, the energy requirement of the engine was relatively lower. Because of this, less amount of fuel was injected and burned in the combustion chamber, producing a lower cylinder temperature. Since NOx formation was prominently dependent on high cylinder temperature, so NOx emission reduced at low loads. However, at the higher load conditions, a higher amount of fuel was injected and burned, producing higher cylinder temperature. DEE10 blend also followed the same trend of low NOx emission at low load and increased NOx emission at high load conditions. However, it was seen that NOx emission for DEE10 was significantly lower than DEE5. It might be due to the reduced ignition delay that reduced the fuel-air mixing time and deteriorated the combustion condition. This reduced combustion of the charge produced lower cylinder heat generation that resulted in lower NOx emission. NOx emission was significantly reduced with the ethanol addition to the diesel-DEE blends. DEE5E5 blend reduced the NOx emission by $14.28 \%$ at full load condition as compared to baseline diesel. This reduction in NOx emission might be attributed to the cooling effect of ethanol. This effect was more prominent for DEE5E10 blend, where it produced a maximum reduction of $20.76 \%$ at medium load condition. For DEE10E5 and DEE10E10 blends, a prominent reduction in NOx emission was also observed. DEE10E5 blend produced a maximum decrease of $25.95 \%$, whereas DEE10E10 blend produced a reduction of $27.58 \%$. Patnaik et al [41] declared that NO emission increased for DEE15 blend by $35 \%$ than that of diesel fuel at full load as seen in Fig. 7(a). Due to low boiling point and presence of molecular oxygen in DEE the mixture improved combustion and higher cetane value of DEE advanced the combustion leading to early-stage combustion during the premixed stage where NO was formed mostly. Karabektas [46] declared that the use of natural gas as a dual fuel (NG40) yielded a decrease in the NO emissions at low and medium loads but an increase at high loads in comparison to diesel fuel. The NO emissions decreased with the use of DEE compared with NG40.

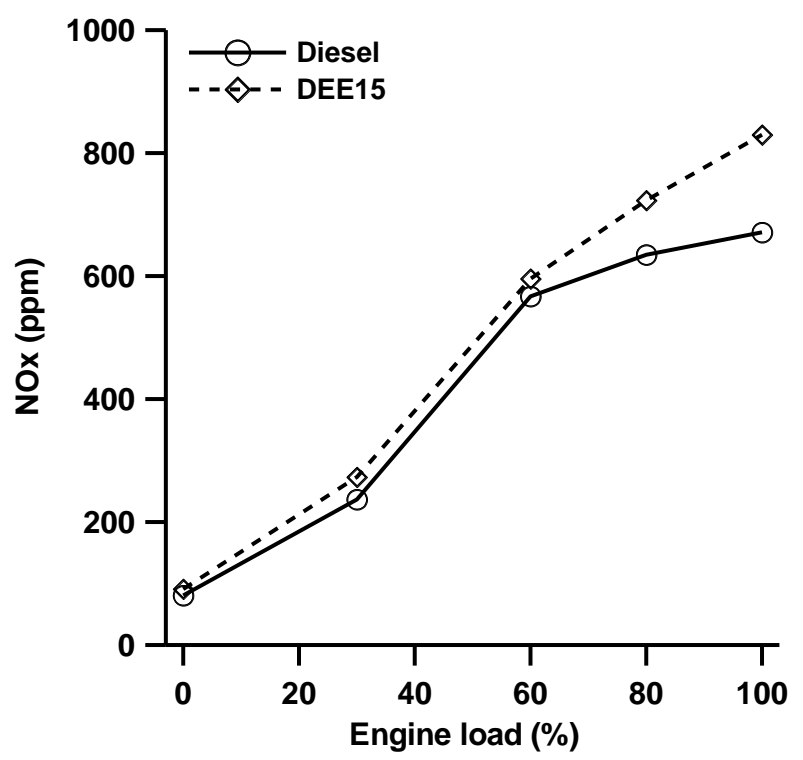

(a)

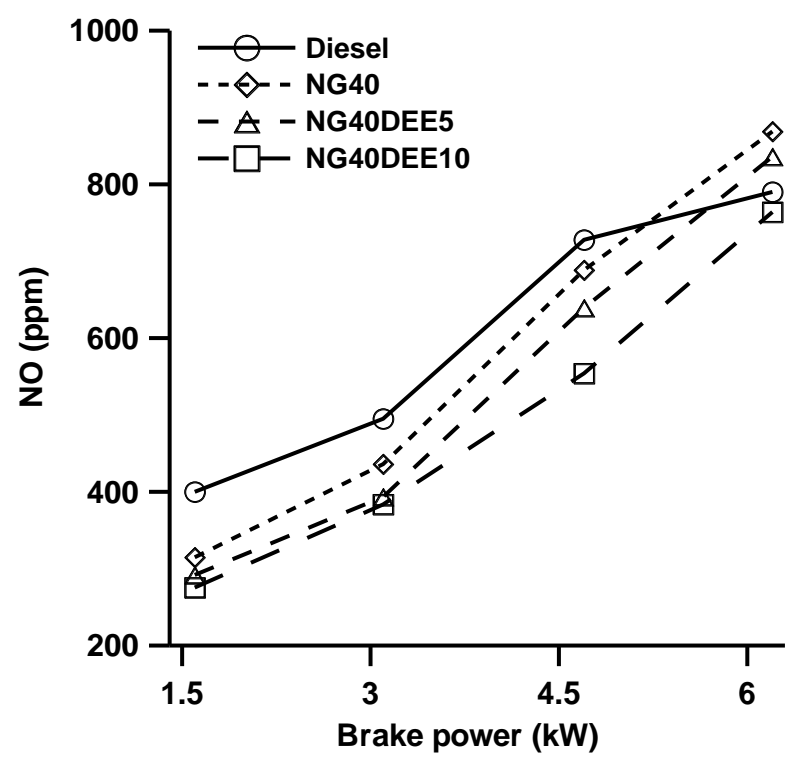

(b)

Fig. 7. Effect of diethyl ether additive on NOx emissions of diesel [41] and natural gas-diesel dual fuel [46]

Furthermore, the higher the DEE content resulted in the lower NO emissions as seen in Fig. 7(b). The decrease in NO emissions obtained with the DEE blends compared with NG40 might originate from various reasons. Because DEE had a considerably high cetane number, oxygen content and high heat of evaporation, it was easy to ignite the fuel-air mixture, and it yielded a shorter combustion duration. By adding DEE, heat release decreased in the stage of diffusion-controlled combustion, thereby leading to lower NO 
emissions. Moreover, DEE blends with oxygen content showed that the NO emissions decreased due to the lower high-temperature duration that the combustion gases experienced. Furthermore, the high cetane number of DEE caused lower NOx emissions particularly at medium-high loads and decreased ignition time and maximum rate of heat release. Another factor which caused lower NO emissions is the high heat of evaporation of DEE.

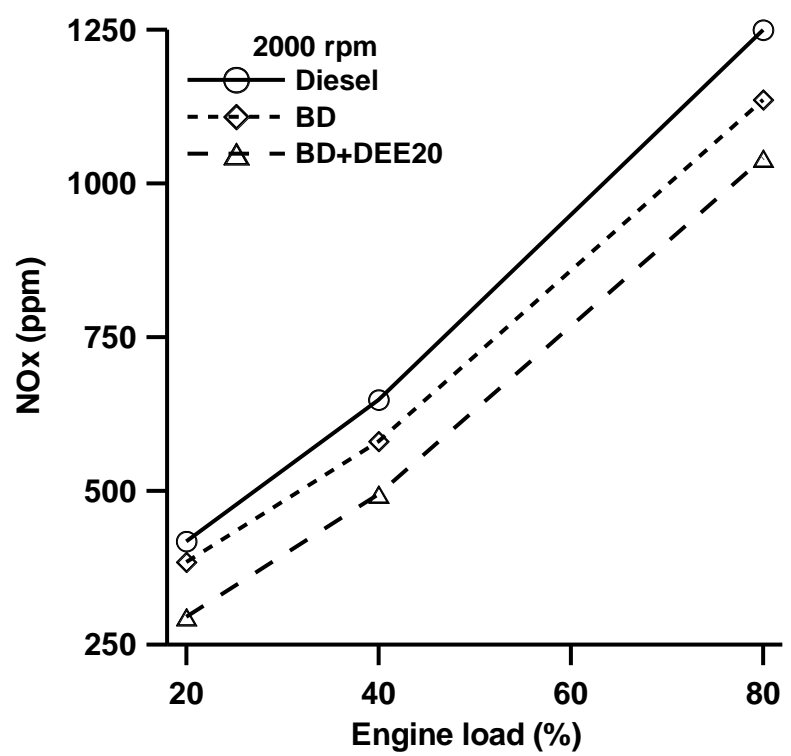

(a)

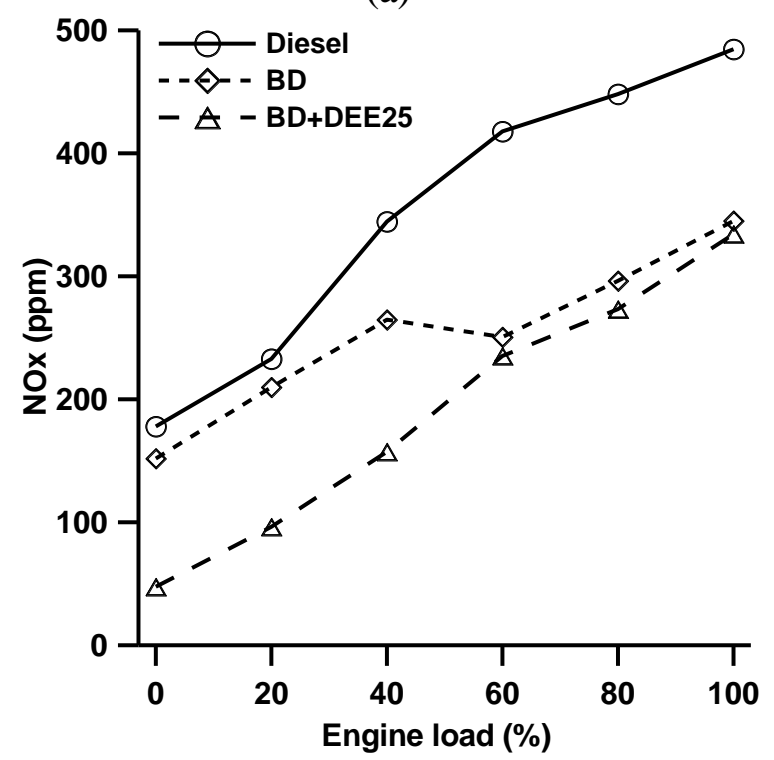

(b)

Fig. 8. Effect of diethyl ether additive on NOx emissions of biodiesel [50, 53]

Rakopoulos [50] declared that NOx emitted by the DEE blends were lower than those of the neat biodiesel and diesel as seen Fig. 8(a). This might be attributed to the relatively reduced premixed part of combustion where NOx was mainly formed and the associated lower cylinder temperatures. Krishna [53] et al declared that NOx emissions were significantly lower for the DEE blends at lower loads, whereas the gap slightly narrowed down at higher load conditions as seen in Fig. 8(b). The important factors for NOx formation were the peak combustion temperature in cylinder and availability of $\mathrm{O}_{2}$ in the combustion chamber. NOx of $25 \%$ DEE blends with Karanja oil operation was $265 \mathrm{ppm}$ as compared to $347 \mathrm{ppm}$ of pure Karanja oil and 488 ppm of pure diesel operation respectively.

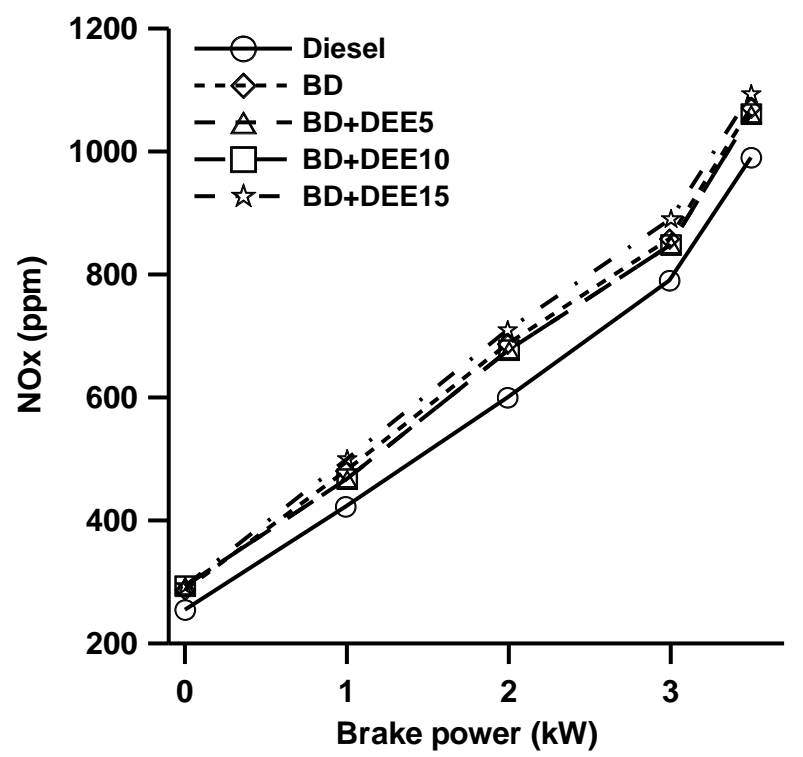

(a)

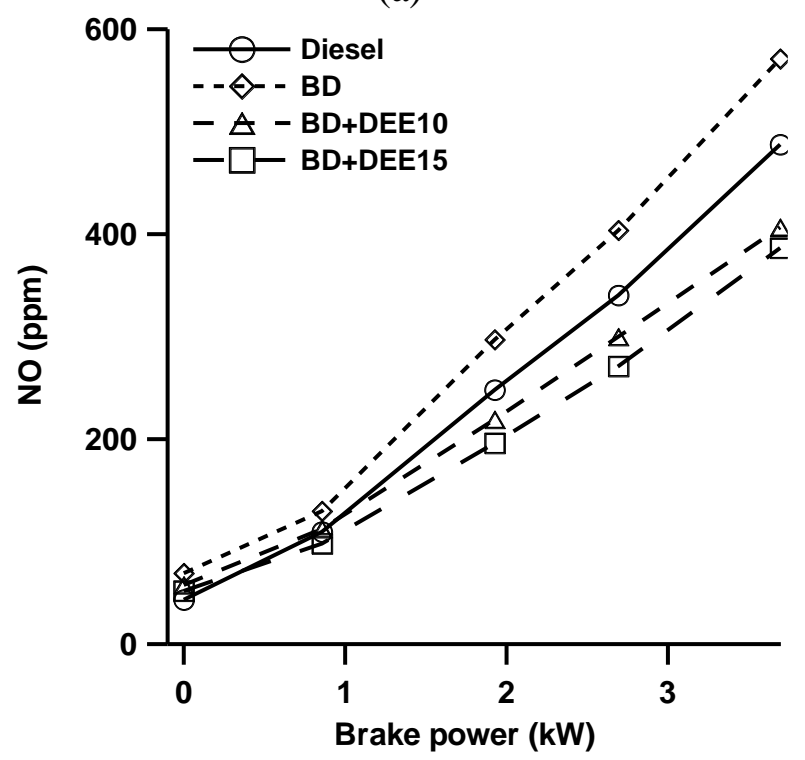

(b)

Fig. 9. Effect of diethyl ether additive on NOx emissions of biodiesel [59, 64]

Sivalakshmi and Balusamy [59] declared that NOx emissions are sensitive to oxygen content, adiabatic flame temperature and spray characteristics. $\mathrm{NO}_{\mathrm{x}}$ emission increased with the 
use of DEE5 as seen in Fig 9(a). This might be due to the more complete combustion which resulted in a higher combustion temperature, leading to higher NOx emissions. NOx emission was lower with DEE10 blend as compared to DEE5. This might be due to a reduction in ignition delay. However, in the case of DEE15 blend, the NOx emission increased. This might be due to higher peak cylinder pressure and heat release rate, which was produced under some erratic conditions, leading to increased NOx emissions.

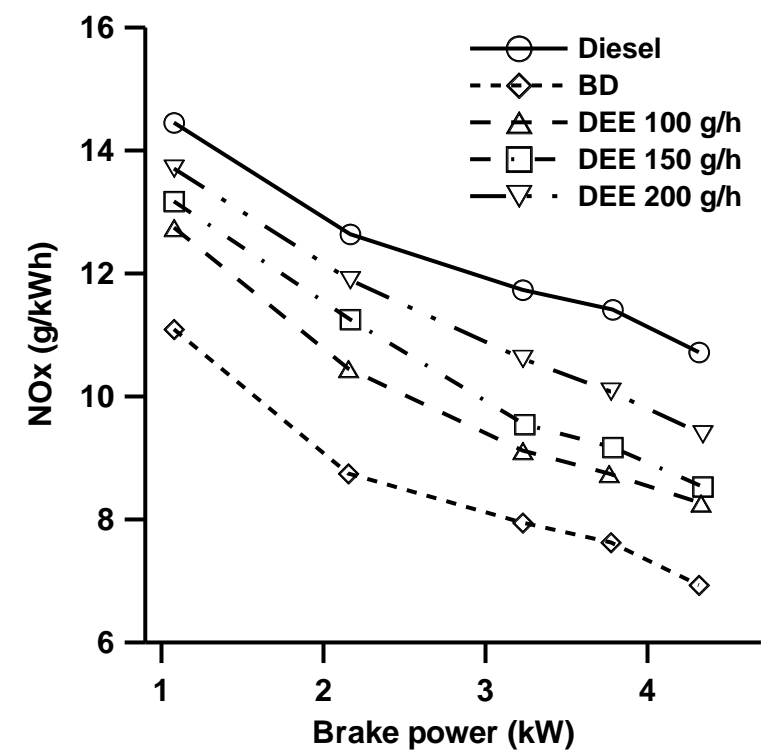

(a)

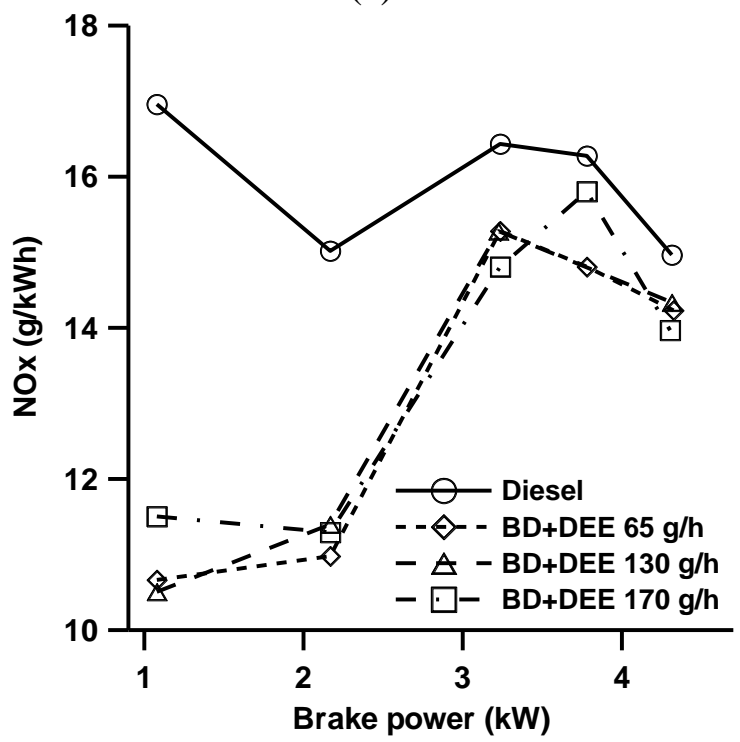

(b)

Fig. 10. Effect of diethyl ether additive on NOx emissions of biodiesel $[65,66]$

Rajan et al [64] declared that NO emission increased for neat biodiesel and it decreased with the increase of DEE in the blends with neat biodiesel at full load as seen in Fig. 9(b). The maximum $\mathrm{NO}$ emissions for $10 \%$ and $15 \%$ DEE are 410 and $385 \mathrm{ppm}$, whereas the same for diesel and neat biodiesel were 486 and 568 ppm, respectively at full load. The NO emission decreased by $32 \%$ for $15 \%$ DEE and $26 \%$ for $10 \%$ DEE at full load compared with neat biodiesel. The decrease in NO emission for DEE might be due to the high latent heat of vaporization of DEE, resulting in cooling the charge at full load compared with biodiesel. Geo et al [65] declared that neat biodiesel showed lower NOx emissions as compared to diesel as seen in Fig. 10(a). The maximum NOx emission was $10.7 \mathrm{~g} / \mathrm{kWh}$ with diesel and $6.9 \mathrm{~g} / \mathrm{kWh}$ with biodiesel at maximum output. Due to poor combustion of the injected fuel during premixed combustion with biodiesel was lower and resulted in lower NOx emissions. But DEE admission with biodiesel increased the NOx emission. The maximum NOx emission was 9.3 $\mathrm{g} / \mathrm{kWh}$ with biodiesel-DEE at the optimum quantity of $200 \mathrm{~g} / \mathrm{h}$. The addition of DEE with biodiesel caused a high temperature, promoted by higher premixed combustion and oxygen enrichment. This was due to the high combustion temperature caused by the early combustion of DEE. The combustion temperature had a strong effect on the production of NOx and therefore if the combustion temperature was higher, the NOx emission would also be higher.

Hariharan et al [66] declared that for diesel operation, NOx varied from $16.9 \mathrm{~g} / \mathrm{kWh}$ at low load to $14.9 \mathrm{~g} / \mathrm{kWh}$ at full load, from 10.7 $\mathrm{g} / \mathrm{kWh}$ at low load to $14.3 \mathrm{~g} / \mathrm{kWh}$ at full load for DEE at $65 \mathrm{~g} / \mathrm{h}$, from $10.4 \mathrm{~g} / \mathrm{kWh}$ at low load to $14.2 \mathrm{~g} / \mathrm{kWh}$ at full load for $130 \mathrm{~g} / \mathrm{h}$ as seen Fig. 10(b). At $170 \mathrm{~g} / \mathrm{h}, \mathrm{NOx}$ varies from $11.5 \mathrm{~g} / \mathrm{kWh}$ at low load to $13.9 \mathrm{~g} / \mathrm{kWh}$ at full load. From the figure, it can be seen that while running on biodiesel with DEE at different flow rates, the NOx value decreased significantly with increase in the flow rate of DEE at low loads. This was due to the induction of a higher quantity of DEE at low load. The latent heat of DEE cooled the intake charge and reduced the peak flame temperature and hence NOx was lower than diesel. At full load, the amount of DEE inducted was less compared to low load and this was the reason for higher NOx formation. NOx values for biodiesel with DEE at $130 \mathrm{~g} / \mathrm{h}$ and $170 \mathrm{~g} / \mathrm{h}$ are lesser compared to biodiesel with DEE at 65 
$\mathrm{g} / \mathrm{h}$. This might be attributed to a reduction in ignition delay.

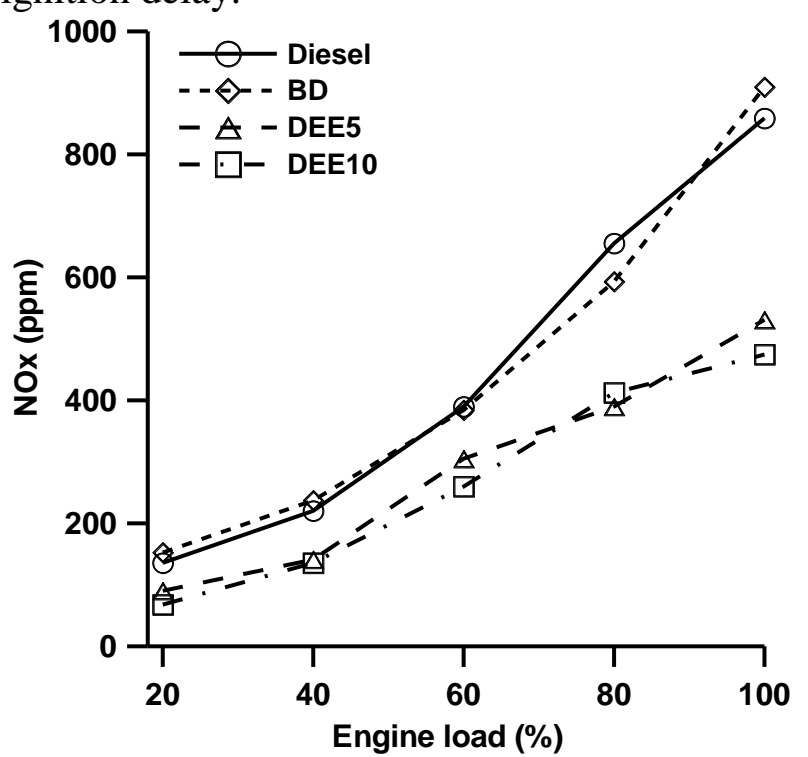

(a)

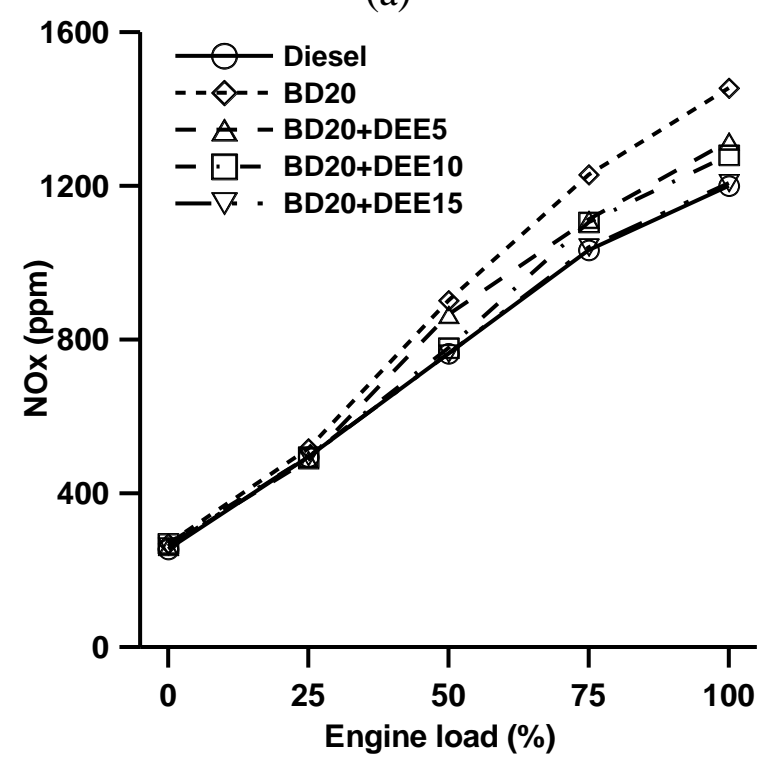

(b)

Fig. 11. Effect of diethyl ether additive on NOx emissions of biodiesel [67] and diesel-biodiesel blends [74]

Devaraj et al [67] declared that NOx values for diesel varied from $129 \mathrm{ppm}$ at $20 \%$ load and 855 ppm at full load as seen in Fig. 11(a). For biodiesel, it varied from $150 \mathrm{ppm}$ at $20 \%$ load and $904 \mathrm{ppm}$ at full load. For DEE5 and DEE10, it varied from 91 to $71 \mathrm{ppm}$ at $20 \%$ load and 529 ppm and $473 \mathrm{ppm}$ at full load. The NOx formed was increasing as the load increased. The NOx emissions of the blends were found to reduce with increasing blend percentage of DEE with biodiesel. Since DEE was a cetane improver and an increase in cetane number decreased NOx emission. DEE has high oxygen content and high heat of evaporation. It was easy to ignite the fuel-air mixture and it yielded shorter combustion duration. By the addition of DEE, heat release decreased in the stage of diffusioncontrolled combustion, thereby leading to lower NOx emissions. Another factor which caused lower NOx emissions was high heat of evaporation of DEE. Because DEE had a considerably high cetane number, oxygen content and high heat of evaporation, it was easy to ignite the fuel-air mixture, and it yielded shorter combustion duration. By adding DEE, heat release decreased in the stage of diffusion controlled combustion, thereby leading to lower NO emissions. Kumar et al [74] declared that NOx emissions of Cashew nut shell oil (CNSO)diesel blend (CDB) are higher than that of diesel fuel as there is a reduction in HRR and combustion temperature. This will result in high NOx concentration in the exhaust. It is observed that NOx for diesel fuel is $1195 \mathrm{ppm}$ and BD20 blend is $1450 \mathrm{ppm}$ as seen in Fig. 11(b). After addition of DEE, NOx for BD20 is $1450 \mathrm{ppm}$ which is higher than that of BD20DEE5 (1327ppm). It means that the addition of DEE in BD20 blends reduces the NOx emission. Srihari et al [76] declared that NOx levels for diesel and BD20 blend are considerably higher than the NOx levels for DEE10 and DEE15 irrespective of the load conditions as seen in Fig. 12(a). However, the DEE5 blend does not show any visible reduction in NOx emissions. The low NOx level of DEE10 and DEE15 could be mainly due to a reduction in combustion temperature with the addition of DEE. It is also seen that the increase in the percentage of DEE significantly decreases the NOx emissions. The main reason for this phenomenon is mainly due to the increase in latent heat of vaporization of the blends with the increasing percentage of DEE. Another reason could be the higher cetane number achieved with the addition of DEE which improves the combustion quality. It is seen that an average reduction of $29.6 \%$ and $22.3 \%$ are achieved for DEE10 blend when compared to BD20 and diesel respectively. The corresponding reductions in NOx level for the DEE15 blend are seen to be $42 \%$ and $46 \%$.

Abraham and Thomas [79] declared that NOx emission increases with brake power for all the fuels as seen in Fig. 12(b). Since the formation of NOx is very sensitive to temperature, these higher loads promote cylinder charge 
temperature, which is responsible for thermal NOx formation. The biodiesel and DEE additives reduce the mean temperature inside the combustion chamber thereby reducing NOx emission.

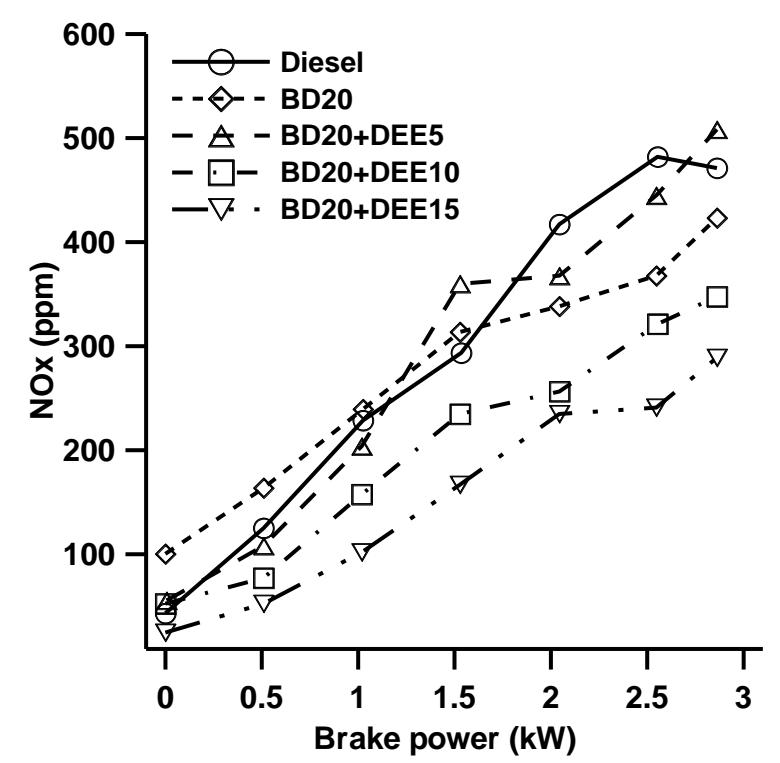

(a)

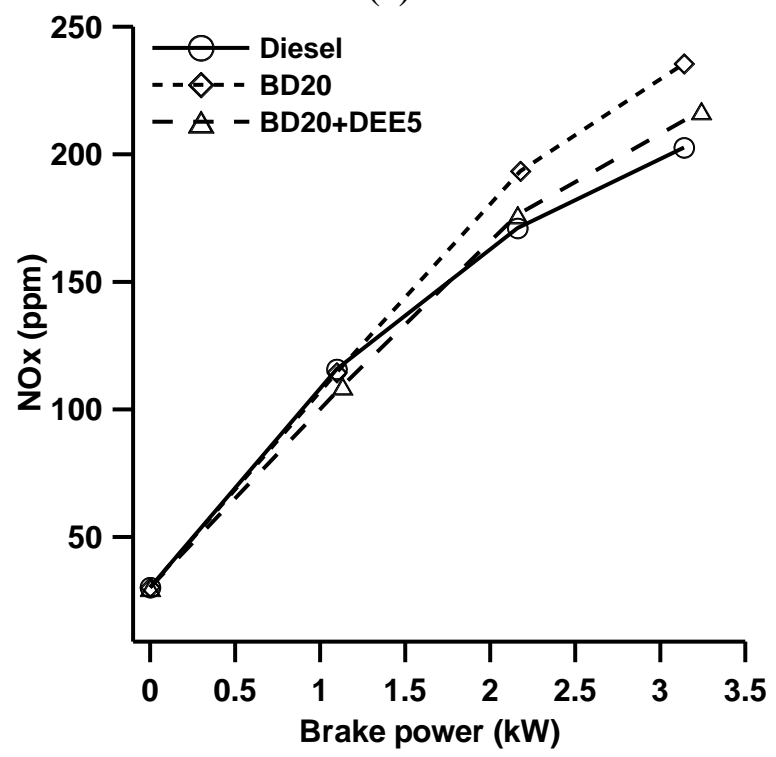

(b)

Fig. 12. Effect of diethyl ether additive on NOx emissions of diesel-biodiesel blends [76, 79]

It is clear from Fig. 13(a) that addition of higher proportions of DEE could reduce NOx levels with the BD20 blend. This may be attributed to the fact that higher quantities of DEE associated with its latent heat of vaporization could bring down the peak cycle temperatures. Prevalence of lower peak cycle temperatures is the reasons for not favoring the thermal prompt reactions responsible for the formation of higher levels of NOx [81]. It is observed from Fig. 13(b) that the $\mathrm{NO}$ emission was increased for BD20 and it is decreased with the increase of DEE in BD20 blend at full load. The maximum NO emissions for DEE10 and DEE15 are 410ppm and $385 \mathrm{ppm}$, whereas for diesel and BD20 are 486ppm and $568 \mathrm{ppm}$ respectively at full load. The NO emission decreased by $32 \%$ for DEE 15 and $26 \%$ for DEE10 at full load compared with BD20 blend. The decrease in NO emission for DEE may be due to the high latent heat of vaporization of DEE results in cooling the charge [83].

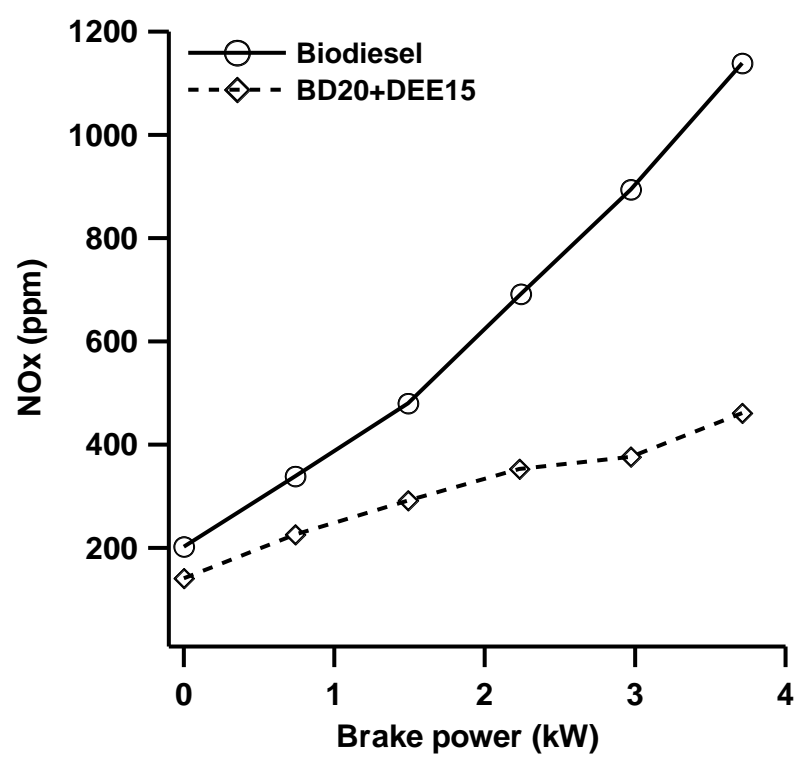

(a)

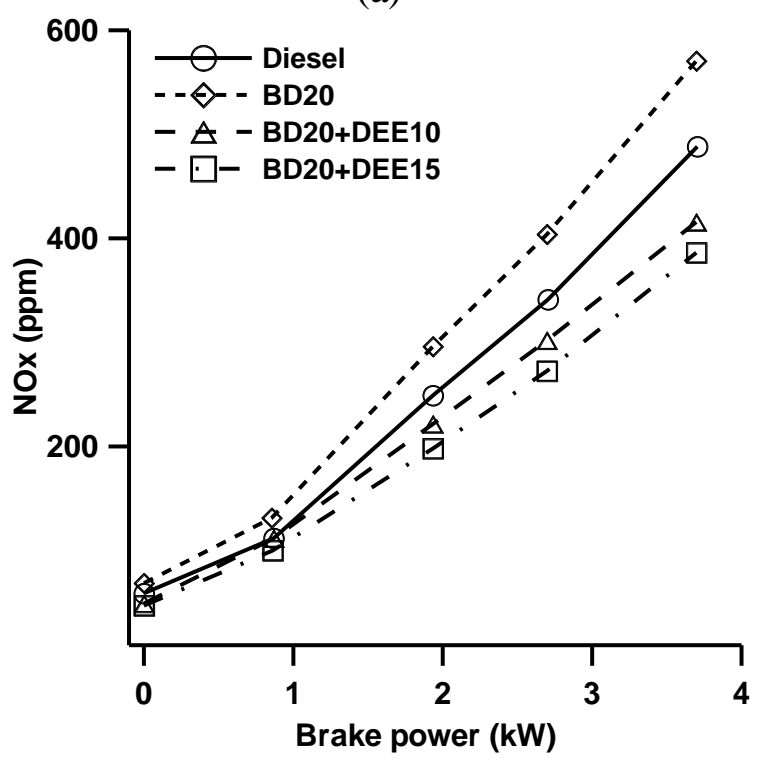

(b)

Fig. 13. Effect of diethyl ether additive on NOx emissions of diesel-biodiesel blends [81, 83]

The NOx concentration varies linearly with engine load as seen in Fig. 14(a). As the load increases, the overall fuel-air ratio increases, resulting in an increase in the average gas temperature in the combustion chamber, and 
hence NOx formation, which is sensitive to temperature increase. At all loads the emission NOx for BD20 is found to be maximum because all vegetable oils are oxygenated intrinsically.

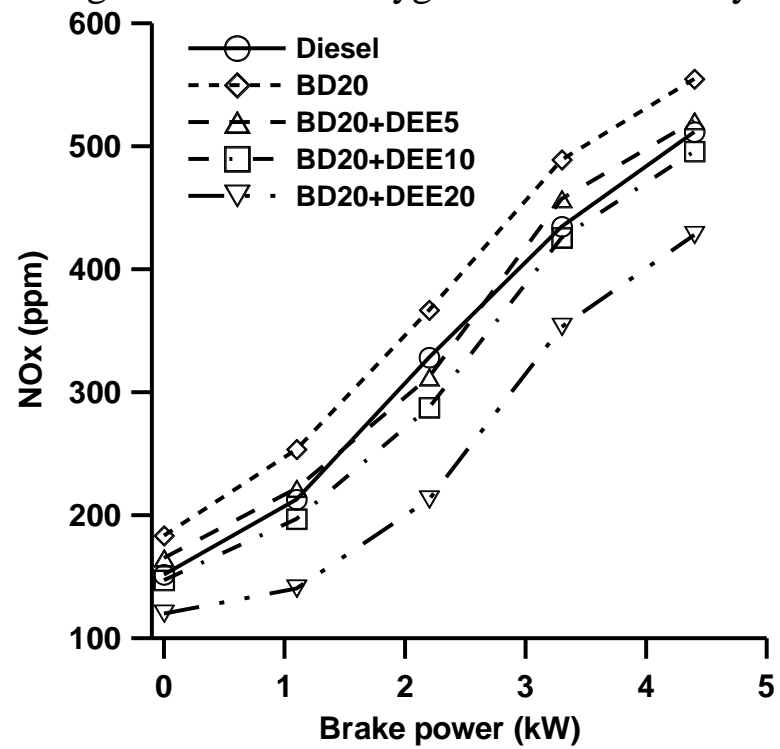

(a)

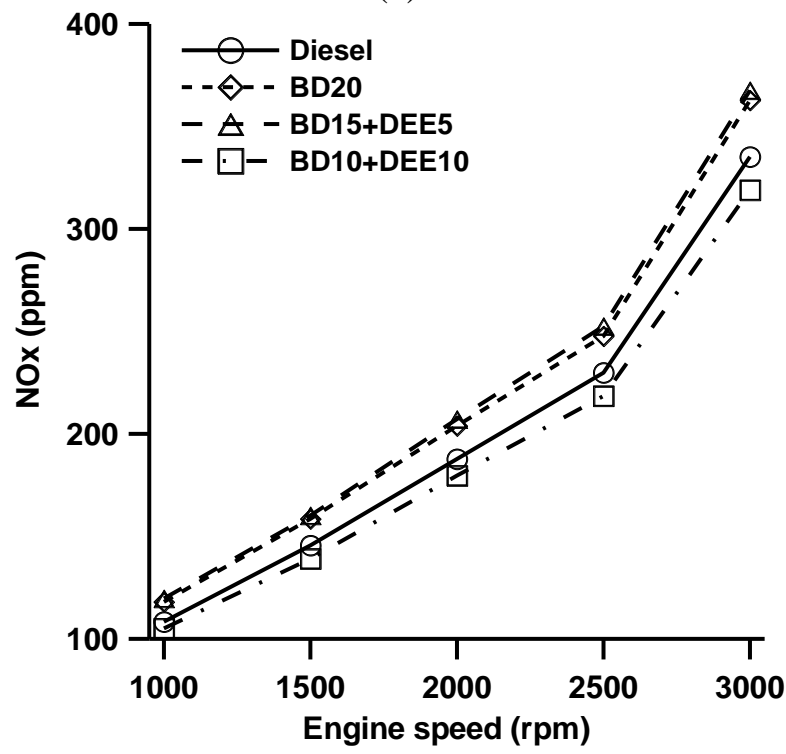

(b)

Fig. 14. Effect of diethyl ether additive on NOx emissions of diesel-biodiesel blends [87, 91]

When small quantities of additives like DEE is started adding the NOx content started reducing [87]. Fig. 14(b) illustrates the NO emission for test fuels. NO formation generally depends on oxygen concentration, air surplus coefficient, cylinder temperature and residence time. In this investigation, BD20 produced $8.2 \%$ higher NO emission on average than diesel. Higher NO for BD20 can be attributed to higher fuel bound oxygen. The higher oxygen content of biodiesel delivers higher local peak temperature which results in higher NO formation. Another reason which can be mentioned is the higher cetane number of biodiesel. Due to higher cetane number, combustion advances, combustion duration reduces and premixed part of the combustion increases where $\mathrm{NO}$ is formed mostly. BD15DEE5 produced slight increased and BD10DEE10 produced about 12\% decreased NO emission than BD20. The higher oxygen content of the DEE blends was the most probable cause for such higher emission of NO. Nevertheless, an increased portion of DEE (BD10DEE10) reduced NO emission than BD20 primarily due to the higher latent heat of evaporation of DEE [91].

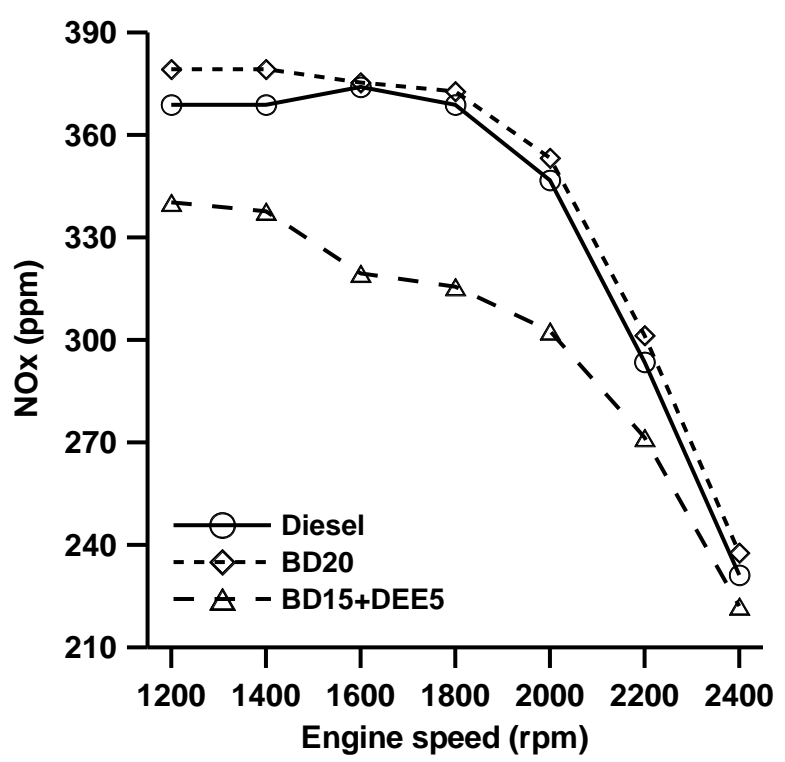

(a)

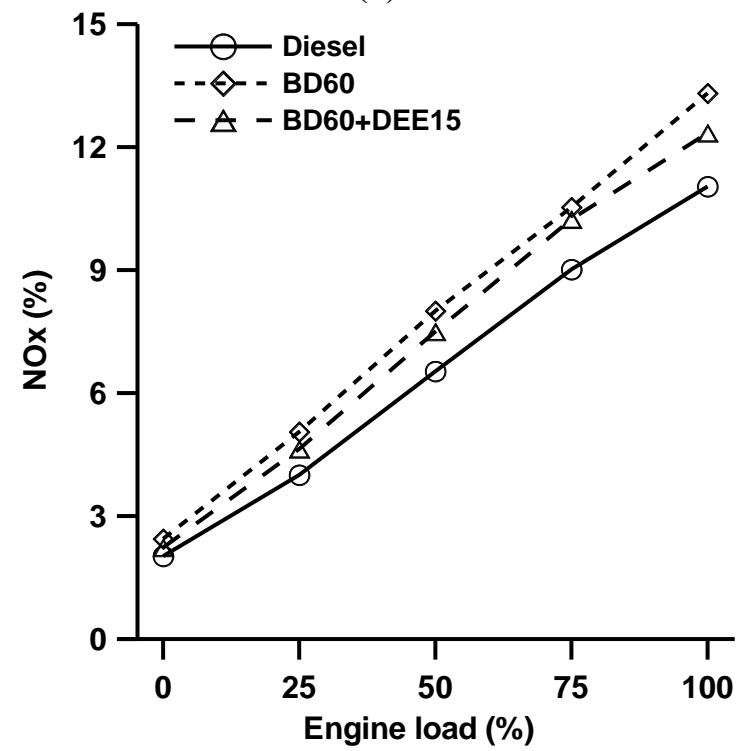

(b)

Fig. 15. Effect of diethyl ether additive on NOx emissions of diesel-biodiesel blends [98, 102]

Fig. 15(a) shows the comparative NOx emission of the diesel and fuel blends. As the speed decreased, NO emission of all the blends 
increased. It can be attributed to the higher available time span of combustion as the speed becomes lower. BD20 showed higher NOx because it contains a higher level of oxygen. However, though DEE has higher oxygen content, BD15DEE5 blend showed lower NO which can be explained by their lower calorific value and higher heat of evaporation which resulted in lower in-cylinder temperature. The lower NOx for BD15DEE5 blend can be also attributed to reduced part of premixed combustion where NO is mainly formed [98]. Fig. 15(b) shows the variation in NOx emissions at different loading conditions. It is observed from the figure that NOx emissions are increased with increase in engine load for all tested fuels. NOx emissions are considerably higher for BD60 blend. The reason biodiesel blend exhibits more NOx emissions is due to excess oxygen and favorable combustion temperature when compared to diesel. NOx is formed when the pressurized air inside the cylinder, having nitrogen constituent reacts with oxygen during combustion at higher temperatures. DEE15 blend showed lesser NOx emissions than BD60 blend at all tested conditions [102].

The parameters affecting the formation of NOx in a diesel engine are; the combustion duration, temperature, higher compression ratio, pressure and the availability of oxygen. The variation of NOx emission with a load for tested fuels depicted in Fig. 16(a). It can be observed from the figure that diesel exhibits the highest NOx emission. Due to the higher density of BD40, the combustion may be incomplete and result in a lower NOx emission for the given power output. The addition of DEE might reduce the cylinder temperature as a result of its higher latent heat of vaporization and this results in lower NOx emissions than that of diesel operation for the given power output. The NOx emission of DEE4 is approximately $25 \%$ lower compared to that of diesel, and about $20 \%$ higher compared to that of BD40 blend at full load [107]. Fig. 16(b) [110] shows the concentration of NOx for BD40E20, DEE5 and DEE10 fuel blends with brake power. NOx emissions are sensitive to oxygen content, adiabatic flame temperature (AFT) and fuel spray characteristics. In general, a fuel ensuring complete combustion will give higher cylinder temperature followed by more
NOx formation. NOx is also formed as a result of thermal mechanisms during the diffusion combustion stage which causes higher incylinder temperature and pressure. Throughout the engine load conditions, DEE addition reduced the NOx invariably.

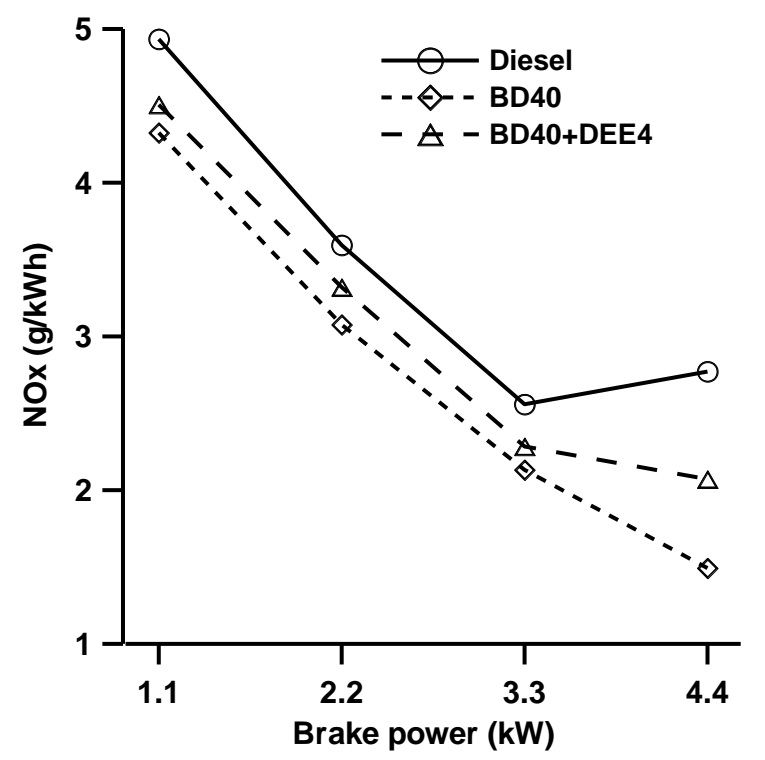

(a)

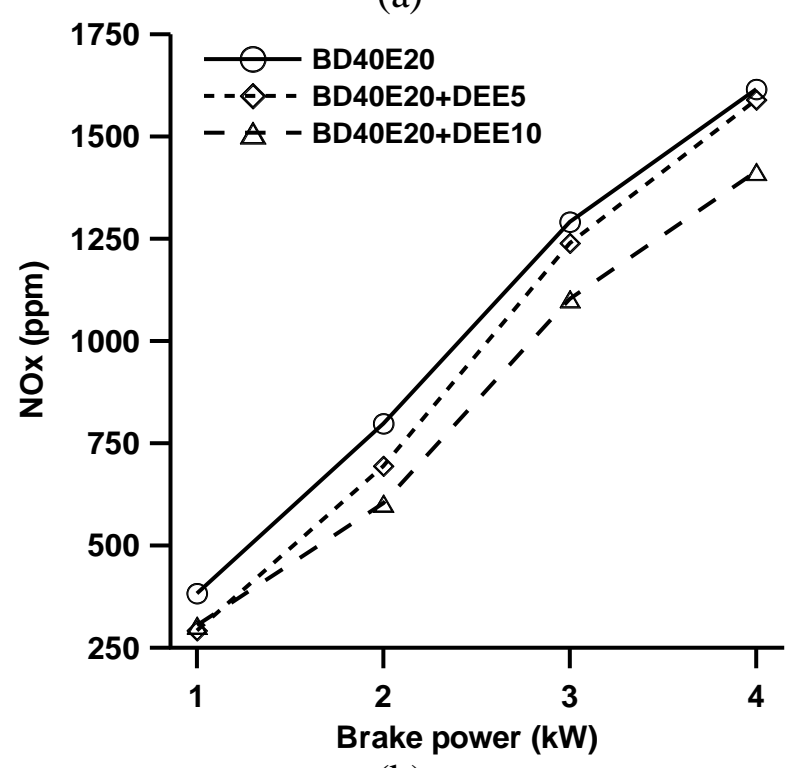

(b)

Fig. 16. Effect of diethyl ether additive on NOx emissions of diesel-biodiesel blends [107] and biodieselethanol blend [110]

Numerical values about diethyl ether addition on NOx emissions are tabulated in Table 2. The ethyl ether addition into various diesel engine fuels provides the decreases in NOx emissions as seen in Table 2.

\section{Conclusions}

The effect of diethyl ether addition to various diesel engine fuels or fuel blends is investigated 
on the NOx emissions in this review study. The following conclusions can be summarized as results of the study.

Table 2. Numerical values about diethyl ether addition on NOx emissions

\begin{tabular}{|c|c|c|}
\hline Base fuel + Additive & $\begin{array}{l}\text { NOx emissions } \\
\text { (variation \%) }\end{array}$ & Ref. \\
\hline$\overline{\mathrm{DEE}}$ & $\downarrow 11.4 \uparrow 164.4$ & [15] \\
\hline $\mathrm{D}+24 \% \mathrm{DEE}$ & $\downarrow 14.4-23.2$ & [17] \\
\hline $\mathrm{D}+20 \% \mathrm{DEE}$ & $\uparrow 11.7-44.4$ & {$[22]$} \\
\hline $\mathrm{D}+50 \% \mathrm{DEE}$ & $\uparrow 3.8-19.1$ & {$[23]$} \\
\hline $\mathrm{D}+5 \% \mathrm{DEE}$ & $\downarrow 1.3-9.9$ & [29] \\
\hline $\mathrm{D}+10 \% \mathrm{DEE}$ & $\uparrow 2-8.6$ & [29] \\
\hline $\mathrm{D}+15 \% \mathrm{BD}+5 \% \mathrm{DEE}$ & $\downarrow 3.8-23.5$ & [31] \\
\hline $\mathrm{D}+30 \% \mathrm{DEE}$ & $\downarrow 20.6$ & {$[32]$} \\
\hline $\mathrm{D}+10 \% \mathrm{E}+15 \% \mathrm{DEE}$ & $\downarrow 17.9-427$ & {$[33]$} \\
\hline $\mathrm{D}+15 \% \mathrm{E}+30 \% \mathrm{DEE}$ & $\uparrow 44.6-111.4$ & {$[35]$} \\
\hline $\mathrm{D}+15 \% \mathrm{DEE}$ & $\uparrow 5-23.6$ & [41] \\
\hline $\mathrm{D}+40 \% \mathrm{NG}+10 \% \mathrm{DEE}$ & $\downarrow 3.3-23.8$ & [46] \\
\hline $\mathrm{BD}+20 \% \mathrm{DEE}$ & $\downarrow 8.4-23.2$ & {$[50]$} \\
\hline $\mathrm{BD}+25 \% \mathrm{DEE}$ & $\downarrow 3.1-68.7$ & {$[53]$} \\
\hline $\mathrm{BD}+15 \% \mathrm{DEE}$ & $\uparrow 2.1-4$ & [59] \\
\hline $\mathrm{BD}+15 \% \mathrm{DEE}$ & $\downarrow 24.4-33.9$ & [64] \\
\hline $\mathrm{BD}+200 \mathrm{~g} / \mathrm{h} \mathrm{DEE}$ & $\downarrow 5.1-12.4$ & {$[65]$} \\
\hline $\mathrm{BD}+170 \mathrm{~g} / \mathrm{h} \mathrm{DEE}$ & $\downarrow 2.9-32.1$ & [66] \\
\hline $\mathrm{BD}+10 \% \mathrm{DEE}$ & $\downarrow 33.3-50$ & [67] \\
\hline $\mathrm{D}+20 \% \mathrm{BD}+15 \% \mathrm{DEE}$ & $\downarrow 2.7-17$ & [74] \\
\hline $\mathrm{D}+20 \% \mathrm{BD}+15 \% \mathrm{DEE}$ & $\downarrow 38.7-58$ & [76] \\
\hline $\mathrm{D}+20 \% \mathrm{BD}+5 \% \mathrm{DEE}$ & $\uparrow 3.1-7.1$ & [79] \\
\hline $\mathrm{D}+20 \% \mathrm{BD}+15 \% \mathrm{DEE}$ & $\downarrow 30.2-59.5$ & [81] \\
\hline $\mathrm{D}+20 \% \mathrm{BD}+20 \% \mathrm{DEE}$ & $\downarrow 22.8-44.6$ & [87] \\
\hline $\mathrm{D}+10 \% \mathrm{BD}+10 \% \mathrm{DEE}$ & $\downarrow 2.9-4.9$ & [91] \\
\hline $\mathrm{D}+15 \% \mathrm{BD}+5 \% \mathrm{DEE}$ & $\downarrow 3.9-14.6$ & [98] \\
\hline $\mathrm{D}+60 \% \mathrm{BD}+15 \% \mathrm{DEE}$ & $\uparrow 10.4-15.7$ & [102] \\
\hline $\mathrm{D}+40 \% \mathrm{BD}+4 \% \mathrm{DEE}$ & $\downarrow 7.6-25.3$ & [107] \\
\hline $\begin{array}{l}\mathrm{D}+40 \% \mathrm{BD}+20 \% \mathrm{E}+ \\
10 \% \mathrm{DEE}\end{array}$ & $\downarrow 3.9$ & [110] \\
\hline
\end{tabular}

- The formation of NOx is a function of flame temperature, the residence time of nitrogen at that temperature and local oxygen concentration in the combustion chamber.

- The properties of DEE which affect the NOx formation are high cetane number, oxygen content, low calorific value, the high latent heat of vaporization. The high cetane number provides a reduced ignition delay period and shortened combustion duration which reduce the NOx emissions. The oxygen content of DEE brings more zones near to stoichiometric conditions, these conditions favour for NOx formation. Additional oxygen results in more complete combustion and increases the temperature of the burned gas, which produces more NOx. Lower calorific value and high latent heat of vaporization resulted in lower cylinder temperatures which generate lower NOx.

- $\quad$ NOx emissions generally increase with the increase of engine load due to increasing combustion temperature while it decreases with increasing engine speed due to the less available time span of combustion.

- $\quad$ The use of alternative fuels i.e. ethanol and natural gas partially effective for the reduction of NOx. Exhaust gas recirculation strategy provides good control over the NOx emissions.

- The addition of diethyl ether to diesel fuel generally causes a reduction in most studies due to lower combustion temperatures. Some researchers reported that there is an increase in the NOx emissions with the addition of the DEE as it helps in complete combustion of the fuel resulting in an increase of combustion chamber temperature.

The addition of diethyl ether to various biodiesel fuels and biodiesel blends generally reduces by improving combustion due to its higher cetane value and available oxygen. Additionally, lower heating value and higher latent heat of vaporization of diethyl ether make an extra contribution to reducing of NOx.

\section{Abbreviations}

$\begin{array}{ll}\text { BD } & : \text { Biodiesel } \\ \text { BD-D } & : \text { Biodiesel-diesel blends } \\ \text { CDB } & \text { : CNSO-Diesel blend } \\ \text { CNSO } & \text { : Cashew nut shell oil } \\ \text { D } & : \text { Diesel }\end{array}$

D-BD-DEE : Diesel-biodiesel-diethyl ether blends

$\begin{array}{ll}\text { DBE } & \text { : Dibutyl ether } \\ \text { DEE } & \text { : Diethyl ether } \\ \text { DGM } & : \text { Diethylene glycol dimethyl } \\ \text { ether } & \\ \text { DMC } & \text { : Dimethyl carbonate } \\ \text { DME } & \text { : Dimethyl ether } \\ \text { DMM } & \text { : Dimethoxy methane } \\ \text { E } & \text { : Ethanol } \\ \text { EGR } & \text { : Exhaust gas recirculation } \\ \text { HCCI } & : \text { Homogenous } \\ \text { compression ignition } \\ \text { K } & : \text { Kerosene } \\ \text { MTBE } & : \text { Methyl tertiary butyl ether } \\ \text { NG } & : \text { Natural gas } \\ \text { NOx } & \text { : Nitrogen oxides } \\ \text { PCCI } & : \text { Partially charge compression } \\ \text { ignition } & \end{array}$


PM

SOx

THC

\section{References}

: Particulate matter

: Sulphur oxides

1. Manikandan R, Sethuraman N. Experimental investigation of nano additive ceric oxide $\left(\mathrm{CeO}_{2}\right)$-ethanol blend on single cylinder four stroke diesel engine. International Journal of Recent Development in Engineering and Technology 2014; 3(2): 24-28.

2. Londhekar AG, Kongre SC. Effects of different additives on performance and emission of biodiesel fuelled compression ignition engine. International Journal of Science and Research 2017; 6(2): 1947-1952.

3. Hagos FY, Ali OM, Mamat R, Abdullah AA. Effect of emulsification and blending on the oxygenation and substitution of diesel fuel for compression ignition engine. Renewable and Sustainable Energy Reviews 2017; 75: 12811294.

4. Patil RN, Marlapalle BG. Karanja (pongamia pinnata) biodiesel as an alternative fuel for DICI engine: A review. International Journal of Research in Aeronautical and Mechanical Engineering 2016; 4(1): 96-101.

5. Geng P, Cao E, Tan Q, Wei L. Effects of alternative fuels on the combustion characteristics and emission products from diesel engines: A review. Renewable and Sustainable Energy Reviews 2017; 71: 523-534. 6. Kumar BR, Saravanan S. Use of higher alcohol biofuels in diesel engines: A review. Renewable and Sustainable Energy Reviews 2016; 60: 84-115.

7. Patil AR, Taji SG. Effect of oxygenated fuel additive on diesel engine performance and emission: a review. Journal of Mechanical and Civil Engineering 2013; X: 30-35

8. Senthilkumar R, Ramadoss K, Manimaran R, Prabu M. Emission, combustion, performance and characteristics of a CI engine using MTBE blended diesel fuel. International Conference on Advances in Engineering, Science and Management (ICAESM); March 30-31, 2012; 360-364.

9. Saravanakumar L, Bapu BRR, Prasad BD. Performance and emission characteristics of a CI engine operating on methyl esters blended diesel with di-methyl carbonate additives. International Energy Journal 2014;
14: 121-132.

10. Jawre SS, Bhagat A, Moghe SM, Pakhale VA. Diethyl ether as additive and its effect on diesel engine performance-a review. Global Research and Development Journal for Engineering 2016; 1(5): 27-31.

11. Chauhan BS, Singh RK, Cho HM, Lim HC. Practice of diesel fuel blends using alternative fuels: A review. Renewable and Sustainable Energy Reviews 2016; 59: 13581368.

12. Valipour A. A review on effect of fuel additives on combustion, performance and emission characteristics of diesel and biodiesel fuelled engine. International Journal of Application or Innovation in Engineering \& Management 2014; 3(1): 366-273.

13. Krishnamoorthi M, Malayalamurthi R. A review on effect of diethyl ether additive on combustion, performance and emission characteristics of a diesel and biodiesel/vegetable oil fuelled engine. Advances in Natural and Applied Sciences 2016; 10(7): 9-17.

14. Bailey B, Eberhardt J, Goguen S, Erwin J. Diethyl ether (DEE) as a renewable diesel fuel. SAE Technical Paper 1997; Paper no: 972978.

15. Sezer I. Thermodynamic, performance and emission investigation of a diesel engine running on dimethyl ether and diethyl ether. International Journal of Thermal Sciences 2011; 50: 1594-1603.

16. Mohan B, Yang W, Yu W, Tay KL. Numerical analysis of spray characteristics of dimethyl ether and diethyl ether fuel. Applied Energy 2017; 185: 1403-1410.

17. Rakopoulos DC, Rakopoulos CD, Giakoumis EG, Dimaratos AM. Characteristics of performance and emissions in high-speed direct injection diesel engine fueled with diethyl ether/diesel fuel blends. Energy 2012; 43: 214224.

18. Rakopoulos DC, Rakopoulos CD, Giakoumis EG, Dimaratos AM. Studying combustion and cyclic irregularity of diethyl ether as supplement fuel in diesel engine. Fuel 2013; 109: 325-335.

19. Patil KR, Thipse SS. The effect of injection timing on the performance and emission of direct injection CI engine running on diethyl ether-diesel blends. International 
Journal of Automotive and Mechanical Engineering 2016; 13 (3): 3773-3787.

20. Rathod PH, Darunde DS. Experimental investigation and performance analysis of diethyl ether (DEE) and tert-amyl ethyl ether (TAEE) blend with diesel in C.I.D.I. engine: a review. International Journal of Research in Science \& Engineering 2015; 2 (1): 137-142.

21. Karthik AV, Kumar SP. Experimental study of 4-stroke diesel engine blending with alternate fuel diethyl ether (DEE) and exhaust gas recirculation (EGR) system. International Journal of Engineering Science and Computing 2016; 6: 7054-7058.

22. Banapurmath NR, Khandal SV, Ranganatha SL, Chandrashekar TK. Alcohol (ethanol and diethyl ethyl ether)-diesel blended fuels for diesel engine applications-a feasible solution. Advances in Automobile Engineering 2015; 4(1): 1-8.

23. Lee S, Kim TY. Performance and emission characteristics of a DI diesel engine operated with diesel/DEE blended fuel. Applied Thermal Engineering 2017; 121: 454-461.

24. Saravanan D, Vijayakumar T, Thamaraikannan M. Experimental analysis of combustion and emissions characteristics of CI engine powered with diethyl ether blended diesel as fuel. Research Journal of Engineering Sciences 2012; 1 (4): 41-47.

25. Ibrahim A. Investigating the effect of using diethyl ether as a fuel additive on diesel engine performance and combustion. Applied Thermal Engineering 2016; 107: 853-862.

26. Likhitha SSS, Prasad BD, Kumar RV. Investigation on the effect of diethyl ether additive on the performance of variable compression ratio diesel engine. International Journal of Engineering Research 2014; 3 (1): 11-15.

27. Kumar RS, Nagaprasad KS. Investigation on diesel engine performance by injecting di-ethyl ether as an additive with exhaust gas recirculation using diesel particulate filter. International Journal of Innovative Research in Science, Engineering and Technology 2014; 3 (8); 15192-15200.

28. Balamurugan T, Nalini R. Comparative study on performance and emission in four stroke diesel engine using different blended fuel. International Journal of Current Research and Development 2016; 4 (1): 58-64.
29. Madhu S, Chaitanya AVK, Bridjesh P. effects of diethyl ether on performance and emission characteristics of a diesel engine using toroidal profile bowl piston by varying injection pressure. International Journal of Mechanical Engineering and Technology 2017; 8 (6): 96106.

30. Danesha D, Manjunath H. Production and characterization of biodiesel from Simarouba Glauca seed oil with diethyl ether as an additive and its performance and emission evaluation on single cylinder, four stroke C.I engine. International Journal of Research in Engineering and Technology 2016; 5 (13): 6468.

31. PrasadaRao BVV, HariBabu N, Ramana $\mathrm{MV}$. The role of oxygenated fuel additive (DEE) along with palm methyl ester and diesel to estimate performance and emission analysis of DI-diesel engine. International Journal of Engineering Research \& Technology 2014; 3 (1): $1-9$.

32. Cinar C, Can Ö, Sahin F, Yucesu HS. Effects of premixed diethyl ether (DEE) on combustion and exhaust emissions in a HCCIDI diesel engine. Applied Thermal Engineering 2010; 30: 360-365.

33. Iranmanesh M. Experimental investigations about the effect of new combination of biofuels on simultaneous reduction of $\mathrm{NO}_{\mathrm{x}}$ and smoke emissions in DIdiesel engine. International Journal of Automotive Engineering 2013; 3 (2), 379-392.

34. Sudhakar S, Sivaprakasam S. Experimental investigation on combustion characteristics in DI diesel engine using diethyl ether fumigation with ethanol blended diesel. International Journal of Renewable Energy Research 2014; 4 (4): 872-878.

35. Sudhakar S, Sivaprakasam S. Effects of diethyl ether fumigation in DI diesel engine using bio ethanol blended diesel. International Journal of Innovation and Scientific Research 2014; 11 (1): 65-71.

36. Sudhakar S, Sivaprakasam S. The effect of exhaust gas recirculation on diethyl ether fumigation in DI diesel engine with ethanol blended diesel. International Journal of Engineering Research \& Technology 2014; 3 (10): 538-548.

37. Paul A, Bose PK, Panua RS, Debroy D. Study of performance and emission 
characteristics of a single cylinder CI engine using diethyl ether and ethanol blends. Journal of the Energy Institute 2015; 88: 1-10.

38. Paul A, Panua RS, Debroy D, Bose PK. Effect of diethyl ether and ethanol on performance, combustion, and emission of single cylinder compression ignition engine. International Journal of Ambient Energy 2017; 38 (1): 2-13.

39. Lukhman MM, Sadees P, Pradeep V, Murali M. Experimental investigation on diethyl ether as an ignition improver in diesel- ethanol emulsified fuel for C.I. engine. International Conference on Systems, Science, Control, Communication, Engineering and Technology 2016; 2: 554-560.

40. Kumar MM, Reddy SSK. Performance characteristics of single cylinder DI diesel engine by using di-ethyl ether as an additive with diesel ethanol blend. International Journal of Science, Engineering and Technology Research 2015; 4 (9): 3272-3275.

41. Patnaik PP, Jena SP, Acharya SK, Das HC. Effect of $\mathrm{FeCl}_{3}$ and diethyl ether as additives on compression ignition engine emissions. Sustainable Environment Research 2017; 27: 154-161.

42. Patil KR, Thipse SS. Experimental investigation of CI engine combustion, performance and emissions in DEE-kerosenediesel blends of high DEE concentration. Energy Conversion and Management 2015; 89: 396-408.

43. Mahla SK, Kumar S, Shergill H, Kumar A. Study the performance characteristics of acetylene gas in dual fuel engine with diethyl ether blends. International Journal on Emerging Technologies 2012; 3 (1): 80-83.

44. Sudheesh K, Mallikarjuna JM. Diethyl ether as an ignition improver for biogas homogeneous charge compression ignition (HCCI) operation-an experimental investigation. Energy 2010; 35: 3614-3622.

45. Jothi NKM, Nagarajan G, Renganarayanan S. Experimental studies on homogeneous charge CI engine fueled with LPG using DEE as an ignition enhancer. Renewable Energy 2007; 32: 1581-1593.

46. Karabektas M, Ergen G, Hosoz M. The effects of using diethylether as additive on the performance and emissions of a diesel engine fuelled with CNG. Fuel 2014; 115: 855-860.
47. Polat S. An experimental study on combustion, engine performance and exhaust emissions in a HCCI engine fuelled with diethyl ether-ethanol fuel blends. Fuel Processing Technology 2016; 143: 140-150.

48. Mack JH, Buchholz BA, Flowers DL, Dibble RW. The effect of the di-tertiary butyl peroxide (DTBP) additive on HCCI combustion of fuel blends of ethanol and diethyl ether. Society of Automotive Engineering 2015; Paper no: 2005-01-2135.

49. Pranesh G, Samuel PM, Thankachan B, Manimaran M, Silambarasan R. Performance and emission characteristics of blending diethyl ether in cotton seed oil methyl ester using a direct injection diesel engine. International Journal on Applications in Mechanical and Production Engineering 2015; 1 (6): 14-16.

50. Rakopoulos DC. Combustion and emissions of cottonseed oil and its bio-diesel in blends with either n-butanol or diethyl ether in HSDI diesel engine. Fuel 2013; 105: 603-613.

51. Rakopoulos DC, Rakopoulos CD, Kyritsis DC. Butanol or DEE blends with either straight vegetable oil or biodiesel excluding fossil fuel: Comparative effects on diesel engine combustion attributes, cyclic variability and regulated emissions trade-off. Energy 2016; 115: 314-325.

52. Rakopoulos DC, Rakopoulos CD, Giakoumis EG, Papagiannakis RG, Kyritsis DC. Influence of properties of various common biofuels on the combustion and emission characteristics of high-speed DI (direct injection) diesel engine: Vegetable oil, biodiesel, ethanol, n-butanol, diethyl ether. Energy 2014; 73: 354-366.

53. Krishna R, Bandewar AG, Dongare VK. Experimental investigations of blending diethyl ether in karanja vegetable oil using a multicylinder diesel engine. International Journal of Research and Innovative Technology 2014; 1 (5): 70-73.

54. Singh I, Sahni V. Performance analysis of the compression ignition engine using karanja biodiesel with additive diethyl ether. Int'l Conference on Aeronautical, Automotive and Manufacturing Engineering 2015; 9-12.

55. Jawre SS, Lawankar SM. Performance analysis of Kusum methyl ester as alternative bio-fuel in diesel engine with diethyl ether as additive. International Journal of Innovative 
Research \& Development 2014; 3 (5): 139-144. 56. Jawre SS, Lawankar SM. Experimental analysis of performance of diesel engine using kusum methyl ester with diethyl ether as additive. International Journal of Engineering Research and Applications 2014; 4 (5): 106111.

57. Rao KP, Reddi VL. Performance evaluation of diesel engine with biodiesel along with additive for replacing diesel fuel. Int. J. Chem. Sci. 2016; 14 (4): 2379-2388.

58. Babu PR, Rao KP, Rao BVA. The role of oxygenated fuel additive (DEE) along with mahuva methyl ester to estimate performance and emission analysis of DI-diesel engine. International Journal of Thermal Technologies 2012; 2(1): 119-123.

59. Sivalakshmi S, Balusamy T. Effect of biodiesel and its blends with diethyl ether on the combustion, performance and emissions from a diesel engine. Fuel 2013; 106: 106-110.

60. Ali OM, Mamat R, Faizal CKM. Effects of diethyl ether additives on palm biodiesel fuel characteristics and low temperature flow properties. International Journal of Advanced Science and Technology 2013; 52: 111-120.

61. Ali OM, Yusaf T, Mamat R, Abdullah NR, Abdullah AA. Influence of chemical blends on palm oil methyl esters' cold flow properties and fuel characteristics. Energies 2014; 7: 43644380 .

62. Kumar JS, Prasad SVM. Experimental study on performance characteristics of C.I. engine fueled with biodiesel and its blends diethyl ether. International Journal \& Magazine of Engineering, Technology, Management and Research 2014; 1 (8): 36-40.

63. Satyanarayanamurthy

YVV. Experimental investigations of real time secondary co-injection of water-diethyl ether solution in DI-diesel engine fuelled with palm kernel methyl ester. Journal of Engineering Science and Technology 2012; 7 (6): 711-721.

64. Rajan K, Prabhahar M, Senthilkumar KR. Experimental studies on the performance, emission and combustion characteristics of a biodiesel-fuelled (pongamia methyl ester) diesel engine with diethyl ether as an oxygenated fuel additive. International Journal of Ambient Energy 2016; 37 (5): 439-445.

65. Geo VE, Nagarajan G, Nagalingam B. Studies on improving the performance of rubber seed oil fuel for diesel engine with DEE port injection. Fuel 2010; 89: 3559-3567.

66. Hariharan S, Murugan S, Nagarajan G. Effect of diethyl ether on tyre pyrolysis oil fueled diesel engine. Fuel 2013; 104: 109-115.

67. Devaraj J, Robinson Y, Ganapathi P. Experimental investigation of performance, emission and combustion characteristics of waste plastic pyrolysis oil blended with diethyl ether used as fuel for diesel engine. Energy 2015; 85: 304-309.

68. Kaimal VK, Vijayabalan P. An investigation on the effects of using DEE additive in a DI diesel engine fuelled with waste plastic oil. Fuel 2016; 180: 90-96.

69. Barik D, Murugan S. Effects of diethyl ether (DEE) injection on combustion performance and emission characteristics of Karanja methyl ester (KME)-biogas fueled dual fuel diesel engine. Fuel 2016; 164: 286-296.

70. Sachuthananthan B, Jeyachandran K. Combustion, performance and emission characteristics of water-biodiesel emulsion as fuel with DEE as ignition improver in a DI diesel engine. Journal of Environmental Research and Development 2007; 2 (2): 164172.

71. Krishnamoorthi M, Malayalamurthi R. Experimental investigation on performance, emission behavior and exergy analysis of a variable compression ratio engine fueled with diesel-aegle marmelos oil-diethyl ether blends. Energy 2017; 128: 312-328.

72. Roy MM, Calder J, Wang W, Mangad A, Diniz FCM. Cold start idle emissions from a modern Tier-4 turbo-charged diesel engine fueled with diesel-biodiesel, diesel-biodieselethanol, and diesel-biodiesel-diethyl ether blends. Applied Energy 2016; 180: 52-65.

73. Kumar A, Rajan K, Naraynan MR, Kumar KRS. Performance and emission characteristics of a DI diesel engine fuelled with Cashew Nut Shell Oil (CNSO)-diesel blends with Diethyl ether as additive. Applied Mechanics and Materials 2015; 787: 746-750.

74. Kumar A, Rajan K, Kumar KRS, Maiyappan K, Rasheed UT. Green fuel utilization for diesel engine, combustion and emission analysis fuelled with CNSO diesel blends with diethyl ether as additive. Materials Science and Engineering 2017; 197: 1-10.

75. Ganesha T, Chethan KS. An 
experimental investigation of the performance and emission of diesel engine fueled with cashew shell oil methyl ester (CSOME) and it's blend with diethyl ether and conventional diesel. Imperial Journal of Interdisciplinary Research 2016; 2 (9): 922-929.

76. Srihari S, Thirumalini S, Prashanth K. An experimental study on the performance and emission characteristics of PCCI-DI engine fuelled with diethyl ether-biodiesel-diesel blends. Renewable Energy 2017; 107: 440-447. 77. Karthick D, Dwarakesh R, Premnath. Combustion and emission characteristics of jatropha blend as a biodiesel for compression ignition engine with variation of compression ratio. International Review of Applied Engineering Research 2014; 4 (1): 39-46.

78. Satya VPU, Murthy KM, Rao GAP. Effective utilization of B20 blend with oxygenated additives. Thermal Science 2011; 15 (4): 1175-1184.

79. Abraham BC, Thomas AJ. Performance evaluation of biodiesel with a combustion enhancer additive. International Journal of Mechanical Engineering and Technology 2015; 6(8): 118-125.

80. Firew D, Babu NR, Didwania M. The performance evaluation of diethyl-ether (DEE) additive with diesel blends using diesel engine test rig. International Journal of Scientific \& Engineering Research 2016; 7(6): 23-29.

81. Prasad USV, Madhu Murthy K, Amba Prasad RG. Effect of oxygenated additives on control of emissions in a DI diesel engine using biodiesel-diesel blends. International Conference on Mechanical, Automobile and Robotics Engineering 2012; 256-260.

82. Biradar CH, Subramanian KA, Dastidar MG. Performance improvement and emissions reduction of a DI diesel engine for use of karanja biodiesel-diesel blend (B20) using diethyl ether. SAE 2011; Paper no: 2011-26-0004.

83. Manickam AR, Rajan K, Manoharan N, Senthil Kumar KR. Experimental analysis of a diesel engine fuelled with biodiesel blend using di-ethyl ether as fuel additives. International Journal of Engineering and Technology 2014; 6 (5): 2412-2420.

84. Channe PK, Kulkarni RK. Performance testing of diesel engine using KME and DEE blends with kerosene: a review. International Journal of Mechanical Engineering 2015; 3(6):
$1-5$.

85. Nagdeote DD, Deshmukh MM. Experimental study of diethyl ether and ethanol additives with biodiesel-diesel blended fuel engine. International Journal of Emerging Technology and Advanced Engineering 2012; 2 (3): 195-199.

86. Vadivel N, Somasundaram $P$, Krishnamoorthi M. Performance and emission characteristics of a CI engine fueled with diesel -biodiesel (mahua/mustard) blend with diethyl ether additive. Journal of Chemical and Pharmaceutical Sciences 2015; 7: 109-115.

87. Mallikarjun MV, Mamilla VR, Rao GLN. NOx emission control techniques when CI engine is fuelled with blends of mahua methyle esters and diesel. International Journal of Engineering Sciences \& Emerging Technologies 2013; 4 (2): 96-104.

88. Sudhakar S, Sivaprakasam S. Potential of diethyl ether blends with biodiesel in DI diesel engine-an experimental investigation. International Journal of Research in Engineering \& Advanced Technology 2014; 2 (5): $1-6$.

89. Krishnamoorthi M. Exergy analysis of diesel engine powered by diesel-mustard biodiesel blend with diethyl ether as additive. Journal of Chemical and Pharmaceutical Research 2015; 7 (8): 809-816.

90. Sathiyamoorthi R, Sankaranarayanan G, Pitchandi K. Combined effect of nanoemulsion and EGR on combustion and emission characteristics of neat lemongrass oil (LGO)DEE-diesel blend fuelled diesel engine. Applied Thermal Engineering 2017; 112: 1421-1432.

91. Imtenan S, Masjuki HH, Varman M, Rizwanul Fattah IM, Sajjad H, Arbab MI. Effect of n-butanol and diethyl ether as oxygenated additives on combustion-emission-performance characteristics of a multiple cylinder diesel engine fuelled with diesel-jatropha biodiesel blend. Energy Conversion and Management 2015; 94: 84-94.

92. Akshatha DS, Manavendra G, Kumarappa S. Performance evaluation of Neem biodiesel on $\mathrm{CI}$ engine with diethyl ether as additive. International Journal of Innovative Research in Science, Engineering and Technology 2013; 2(8): 3729-3736.

93. Kumar JV, Rao CJ. Experimental investigation of performance and emission 
characteristics of diesel engine working on diesel and neem oil blend with diethyl ether as additive. International Journal of Technological Exploration and Learning 2014; 3(5): 581-588.

94. Annamalai K, Kumar ARP, Premkartik K. Adelfa (NOME-Nerium Oil Methyl Ester) with DEE as the fuel additive for NOx reduction in DI Diesel engines-An experimental investigation. Journal of Scientific \& Industrial Research 2014; 73: 627-632.

95. Ali OM, Mamat R, Masjuki HH, Abdullah AA. Analysis of blended fuel properties and cycle-to-cycle variation in a diesel engine with a diethyl ether additive. Energy Conversion and Management 2016; 108: 511-519.

96. Ali OM, Mamat R, Najafi G, Yusaf T, Ardebili SMS. Optimization of biodiesel-diesel blended fuel properties and engine performance with ether additive using statistical analysis and response surface methods. Energies 2015; 8: 14136-14150.

97. Ali OM, Mamat R, Abdullah NR, Abdullah AA. Investigation of blended palm biodiesel-diesel fuel properties with oxygenated additive. Journal of Engineering and Applied Sciences 2016; 11(8): 5289-5293.

98. Imtenan S, Masjukia HH, Varmana M, Arbaba MI, Sajjada H, Rizwanul Fattaha IM, Abedina MJ, Md. Hasib AS. Emission and performance improvement analysis of biodieseldiesel blends with additives. Procedia Engineering 2014; 90: 472-477.

99. Imtenan S, Varman M, Masjuki HH, Kalam MA, Sajjad H, Arbab MI. Effect of DEE as an oxygenated additive on palm biodieseldiesel blend in the context of combustion and emission characteristics on a medium duty diesel engine. 4th International Conference on Environmental, Energy and Biotechnology 2015; 85: 100-104.

100. Varaprasad KS, Rao HSB. Experimental investigation on engine performance and exhaust emission analysis of diesel engine operating on palm oil biodiesel blends with diethyl ether as an additive. International Journal of Research and Innovation 2017.

101. Muneeswaran R, Thansekhar MR, Varatharajan K. Effect of diethyl ether addition to palm stearin biodiesel blends on NOx emissions from a diesel engine. Asian Journal of Research in Social Sciences and Humanities
2016; 6 (9): 1382-1394.

102. Samuel KJ, Raj RTK, Sreenivasulu N, Rajasekhar Y, Edison G, Saco SA. An experimental study on performance and emissions of a direct ignition diesel engine with crude pongamia, pongamia methyl ester and diethyl ether blended with diesel. International Journal of Renewable Energy Research 2016; 6 (4): 1506-1515.

103. Pugazhvadivu M, Rajagopan S. Investigations on a diesel engine fuelled with biodiesel blends and diethyl ether as an additive. Indian Journal of Science and Technology 2009; 2 (5): 31-35.

104. Muneeswaran R, Thansekhar MR. Reduction of NOx emission in biodiesel (soyabean) fuelled DI diesel engine by cetane improver. Journal of Engineering and Applied Sciences 2015; 10 (7): 2968-2973.

105. Navaneethakrishnan P, Vasudevan D. Experimental study on performance and exhaust emission characteristics of a C.I. engine fuelled with tri compound oxygenated diesel fuel blends. Indian Journal of Science and Technology 2015; 8 (4): 307-313.

106. Tudu K, Murugan S, Patel SK. Effect of diethyl ether in a DI diesel engine run on a tyre derived fuel-diesel blend. Journal of the Energy Institute 2016; 89: 525-535.

107. Murugan S, Tudu K, Patel SK. Performance and emission studies of a naturally aspirated diesel engine. Journal of Clean Energy Technologies 2017; 5 (5): 359-365.

108. Krishnamoorthi M, Natarajan A. Performance and emission characteristics of a CI engine fueled with diesel-waste fried oil blend with DEE as additive. International Journal for Research in Applied Science \& Engineering Technology 2015; 3 (5): 65-72.

109. Senthil R, Sivakumar E, Silambarasan R. Effect of diethyl ether on the performance and emission characteristics of a diesel engine using biodiesel-eucalyptus oil blends. RSC Advances 2015; 5: 54019-54027.

110. Venu H, Madhavan V. Effect of diethyl ether and $\mathrm{Al}_{2} \mathrm{O}_{3}$ nano additives in dieselbiodiesel-ethanol blends: performance, combustion and emission characteristics. Journal of Mechanical Science and Technology 2017; 31 (1): 409-420.

111. Venu H, Madhavan V. Effect of nano additives (titanium and zirconium oxides) and 
diethyl ether on biodiesel-ethanol fuelled CI engine. Journal of Mechanical Science and Technology 2016; 30 (5): 2361-2368.

112. Qi DH, Chen H, Geng LM, Bian YZ. Effect of diethyl ether and ethanol additives on the combustion and emission characteristics of biodiesel-diesel blended fuel engine. Renewable Energy 2011; 36: 1252-1258.

113. Venu H, Madhavan V. Influence of diethyl ether (DEE) addition in ethanolbiodiesel-diesel (EBD) and methanol-biodieseldiesel (MBD) blends in a diesel engine. Fuel 2017; 189: 377-390. 